FEDERAL RESERVE BANK OF SAN FRANCISCO

WORKING PAPER SERIES

\title{
Measuring the Effect of the Zero Lower Bound on Monetary Policy
}

\author{
Carlos Carvalho \\ Central Bank of Brazil \\ PUC-Rio \\ Eric Hsu \\ University of California, Berkeley \\ Fernanda Nechio \\ Federal Reserve Bank of San Francisco
}

December 2016

Working Paper 2016-06

http://www.frbsf.org/economic-research/publications/working-papers/wp2016-06.pdf

\section{Suggested citation:}

Carvalho, Carlos, Eric Hsu, Fernanda Nechio. 2016. "Measuring the Effect of the Zero Lower Bound on Monetary Policy.” Federal Reserve Bank of San Francisco Working Paper 2016-06. http://www.frbsf.org/economic-research/publications/working-papers/wp2016-06.pdf

The views in this paper are solely the responsibility of the authors and should not be interpreted as reflecting the views of the Federal Reserve Bank of San Francisco or the Board of Governors of the Federal Reserve System. 


\title{
Measuring the Effect of the Zero Lower Bound on Monetary Policy*
}

\author{
Carlos Carvalho \\ Central Bank of Brazil \\ PUC-Rio
}

\author{
Eric Hsu \\ UC Berkeley
}

December, 2016

\begin{abstract}
The Zero Lower Bound (ZLB) on interest rates is often regarded as an important constraint on monetary policy. To assess how the ZLB affected the Fed's ability to conduct policy, we estimate the effects of Fed communication on yields of different maturities in the pre-ZLB and ZLB periods. Before the ZLB period, communication affects both shortand long-dated yields. In contrast, during the ZLB period, the reaction of yields to communication is concentrated in longer-dated yields. Our findings support the view that the ZLB did not put such a critical constraint on monetary policy, as the Fed retained some ability to affect long-term yields through communication.
\end{abstract}

JEL classification codes: E43, E52, E58

Keywords: communication, forward guidance, zero lower bound.

${ }^{*}$ We thank Fernando Cordeiro for collaboration in the early stages of this project, Andrew Tai for his excellent research assistance, Jens Christensen for numerous exchanges throughout the process, and seminar participants at the EEA 2016. The views expressed in this paper are those of the authors and do not necessarily reflect the position of the Federal Reserve Bank of San Francisco, the Federal Reserve System, or the Central Bank of Brazil. E-mails: cvianac@econ.puc-rio.br, eric.hsu@berkeley.edu, fernanda.nechio@sf.frb.org. 


\section{Introduction}

The Zero Lower Bound (ZLB) on interest rates is often regarded as an important constraint on the ability of central banks to conduct monetary policy. Indeed, if changing the current level of the policy rate were the only tool available to the monetary authority, the ZLB would not be just any constraint — once binding, it would completely hamper its ability to undertake stimulative policies. However, so-called unconventional monetary policies, such as asset purchases and active use of communication to shape expectations about future interest rate policy, can mitigate the limitations imposed by the ZLB. Taken to the limit, if unconventional policies were a perfect substitute for interest rate policy, the ZLB would not be a constraint on policy at all.

In a recent paper, Swanson and Williams (2014) argue that the ZLB has not been such an important constraint on U.S. monetary policy. They estimate how yields of various maturities respond to macroeconomic news over rolling subsamples, effectively allowing the relationship between yields and macroeconomic news to vary over time. They find that during the ZLB period, the sensitivity of shorter-term yields (up to 2 years) to macroeconomic surprises dropped significantly. In contrast, the sensitivity of longer-dated yields to those surprises did not change nearly as much. Based on these findings, they conclude that the ZLB has not been such a critical constraint on policy, as the Fed has retained room to affect the economy.

The key insight that allows Swanson and Williams (2014) to identify the severity of the ZLB constraint is the comparison of the sensitivity of yields to macroeconomic surprises during different periods, namely, before and during the ZLB period. This strategy leads them to conclude that monetary policy has not been all that constrained by the ZLB, as longer-dated yields still had room to fluctuate.

In this paper, we build on their insight to provide more direct evidence on whether and how the ZLB has constrained the Fed's ability to conduct monetary policy. We do so by estimating the effects of Fed communication on yields of different maturities in the pre-ZLB and ZLB periods. Neither of the other two policy tools - interest rates and balance sheet operations were actively employed during both the pre-ZLB and ZLB periods. Therefore, we focus on the only policy tool that allows a direct assessment of the extent to which the ZLB poses a relevant constraint on policy.

Specifically, we compare the effects of Fed communication on various yields during normal times (i.e, away from the ZLB) and during the 2008-2014 ZLB period. To that end, we rely on the methodology developed by Lucca and Trebbi (2011) to quantify the content of Fed communication. They propose a semantic orientation measure that quantifies Fed communication in terms of its "hawkish/dovish" content, as revealed in newspaper and magazine articles related 
to Fed announcements. We proceed in analogy to Swanson and Williams (2014) and regress the changes in yields of various maturities on communication (and interest rate) surprises, splitting the sample into the pre-ZLB and ZLB periods. Our sample includes days on which Federal Open Market Committee (FOMC) meeting statements were released, as well as days on which there was a testimony in Congress by the Chair of the Federal Reserve. We focus on the period from May 1999 to December 2014, with a total of 240 communication dates.

We find that the reaction of yields to communication surprises during the ZLB period is concentrated in medium- to long-term yields (2-10 years). This differs from normal times, during which communication also affects shorter-dated yields. Our findings suggest that the ZLB did not put such a critical constraint on the ability of the Fed to affect longer-dated yields through communication. However, it did mute the response of short-dated yields to communication surprises, which is consistent with Swanson and Williams's (2014) results. Our use of measures of communication, over which the Fed has direct control, rather than macroeconomic surprises in general, gives more credence to the conclusion that the Fed has retained some ability to conduct monetary policy during the ZLB period.

A legitimate concern with respect to the news-based measure of communication is that news articles might just reflect the markets' reactions to Fed announcements. These reactions could shape how the press perceives Fed announcements (i.e., as hawkish as dovish), and "cause" the changes in news-based measure of communication. In that case, our empirical results would suffer from reverse causality.

To address this concern, we construct an alternative measure of communication that focuses on news articles that were almost certainly not affected by market reactions. In particular, for this alternative measure we use only news articles published immediately after the FOMC announcement. These articles were almost certainly produced by the press during the news embargo that precedes the release of each FOMC statement. Our results using this alternative measure corroborate our finding that during the ZLB period the effects of Fed communication concentrate on longer-dated yields, suggesting that our main results are not driven by reverse causality.

One may also express a concern that the Lucca and Trebbi (2011) measure of communication only captures the article writers' perceptions of Fed communication - as opposed to being an objective measure of the information content of Fed announcements. However, it is not Fed communication, per se, that matters for the transmission of monetary policy. Fed communication acts as a policy impulse, and it is the public's and markets' perceptions of that communication that shape expectations and actions, and hence, affect the economy. Put differently, Fed communication does not exist in a vacuum, and the measure of communication that we use captures 
precisely what is of interest: how agents perceive the Fed's communication. ${ }^{1}$

Our paper builds on Swanson and Williams (2014) to provide complementary evidence on the effects of the ZLB constraint on monetary policy. It also relates to Gürkaynak, Sack and Swanson (2005), Campbell et al. (2012) and Swanson (2015). Gürkaynak, Sack and Swanson (2005) use principal component analysis to extract two factors from changes in short-term yields on Fed communication dates, one of which can be interpreted as a measure of Fed communication ("path factor"). Campbell et al. (2012) use this measure of communication to investigate the effects of forward guidance on Treasury and corporate yields in the pre-crisis (1990-2007) and crisis periods (2007-2011). They distinguish between "Odyssean" and "Delphic" forward guidance by exploring revisions to private sector forecasts in response to the Gürkaynak, Sack and Swanson (2005)'s "path factor." Swanson (2015) uses a similar technology to extract factors from a richer set of yields and disentangle the effects of forward guidance and LSAP announcements on asset prices during the ZLB period.

Differently from these papers, we focus on the comparison of the effects of forward guidance in the pre-ZLB and ZLB periods. We do so by exploring a semantic-based measure of communication (but without speaking to the distinction between different types of forward guidance). For completeness, however, we also entertain a yield-based measure of Fed communication following Gürkaynak, Sack and Swanson (2005) and Swanson (2015). Results using this yield-based measure corroborate our findings.

Our paper also speaks to a large body of work on the effects of forward guidance at the ZLB. Eggertsson and Woodford (2003) discuss the transmission mechanism of monetary policy at the ZLB in a dynamic stochastic general equilibrium model, and argue that a recession can be reversed if the central bank is able to commit to keeping interest rates low for a long period. Other papers have also analyzed the effects of forward guidance in New Keynesian models. For example, Carlstrom, Fuerst and Paustian (2012) show that a promise to hold interest rates below steady state can generate unreasonably large effects on inflation and output in these models, suggesting that the New Keynesian framework overestimates the effects of forward guidance. Del Negro, Giannoni and Patterson (2015) reach a similar conclusion in an estimated DSGE model that incorporates market expectations for the short-term rate, showing that the model predicts excessive response of long-term yields to announcements about future short-term rates. McKay, Nakamura and Steinsson (2015) find that models that assume incomplete markets imply a much more limited effect of communication. Bassetto (2015) studies the strategic interaction between the public and the central bank and how forward guidance emerges as a communication

\footnotetext{
${ }^{1}$ Of course, the news-based measure only captures the press' perceptions of Fed communication, and hence, it can be seen as a (noisy) proxy for the public's perceptions.
} 
strategy when the central bank has an informational advantage. Hansen and McMahon (2016) analyze how Fed communication regarding economic conditions and forward guidance affect financial markets and real variables.

Finally, our paper contributes indirectly to an extensive literature on the effects of other unconventional monetary policies - namely, balance-sheet operations - during the ZLB. This literature includes, among others, Krishnamurthy and Vissing-Jorgensen (2011), Cúrdia and Woodford (2011), Swanson (2011), Chen, Cúrdia and Ferrero (2012), and Bauer and Rudebusch (2014). For a survey, see Williams (2011).

The rest of the paper proceeds as follows. Section 2 describes our empirical methodology and data. Section 3 presents our main and some robustness results. In Section 4 we assess our communication measures. In Section 5 we revisit our analysis using yield-based measures of communication. The last section concludes.

\section{Empirical strategy and data}

To study how Treasury yields respond to Fed communication, we estimate the following regression by ordinary least squares:

$$
\Delta y_{d}^{m}=\alpha^{m}+\beta^{m} C S_{d}+\gamma^{m} M S_{d}+\varepsilon_{d}^{m},
$$

where $\Delta y_{d}^{m}$ is the change in Treasury yields for maturity $m$ around a "communication date" $d$, and $C S_{d}$ and $M S_{d}$ are measures of, respectively, communication and interest rate surprises on that communication date.

Equation (1) is estimated separately for the pre-ZLB and the ZLB periods. In our baseline sample, we consider dates of FOMC statement releases and dates of congressional testimonies by the Chair of the Federal Reserve Board to be Fed communication dates. Our pre-ZLB sample covers the period from May 18, 1999 to December 15, 2008, and the ZLB period goes from December 16, 2008 to December 17, 2014. ${ }^{2}$ This yields a total of 133 FOMC statements and 107 testimonies, of which 49 statements and 40 speeches are in the ZLB period. ${ }^{3}$

Our baseline analysis focuses on Treasury yields of 3-month, 6-month, 2-year, 5-year, and 10-year maturities $(m)$, and uses daily data. ${ }^{4}$ Changes in yields $\left(\Delta y_{d}^{m}\right)$ are calculated using end-of-day values between the day of and the day before the communication date. Our main reason to focus on daily data is the fact that the timing of testimonies by the Chair is less well-

\footnotetext{
${ }^{2}$ Starting in May 1999, the FOMC began to release statements following every FOMC meeting.

3 Table A1 in the Appendix lists all communication dates included in our sample.

${ }^{4}$ Daily "on-the-run" Treasury yields data are obtained from Bloomberg.
} 
defined than that of FOMC statements, as testimonies entail the release of a speech, followed by questions by meeting participants. For completeness, in Section 3.2, we revisit our analysis using intraday data for the more limited sample that includes FOMC statement release dates only and show that our results are qualitatively unchanged.

To measure communication surprises $\left(C S_{d}\right)$, we consider the semantic-based measure of communication developed by Lucca and Trebbi (2011), which uses newspaper and magazine articles to quantify the content of Fed communication. To measure interest rate surprises, we follow Kuttner (2001). We describe these measures below. ${ }^{5}$

Following Lucca and Trebbi (2011), we construct the Factiva Semantic Orientation (FSO), a news-based measure of Fed communication. To construct FSO for a given time period, we first collect from the Factiva - a database of articles from major worldwide newspapers - all news articles (in English) that contain the words "Fed," "Federal Reserve," or "FOMC" in the headline. Subsequently, we use a Python script to keep only sentences that contain at least one of the following sets of words: \{rate, policy, statement, announcement, Fed, FOMC, Federal Reserve\}. We call these sentences the "relevant sentences." We then count the number of times the words "hawkish" and "dovish" appear in relevant sentences in those articles, and construct the FSO measure of Fed communication for a period $t$ as: $:^{6,7}$

$$
F S O_{t}=\ln \left(\frac{1+H_{t}}{1+D_{t}}\right)
$$

where $H_{t}$ is the number of times the word "hawkish" appears in relevant sentences in articles published during period $t$, and $D_{t}$ is the number of times the word "dovish" appears in relevant sentences in the same pool of articles. ${ }^{8}$

For the purpose of estimating equation (1), however, we need a measure of communication surprises - i.e. the degree of "hawkishness" or "dovishness" of Fed communication above and beyond what was already expected by market participants, and hence reflected in asset prices. To that end, for each communication date $d$, we use a three-day window to construct our

\footnotetext{
${ }^{5}$ In Section 5 we compare our results to those obtained using a yield-based measure of communication based on Gürkaynak, Sack and Swanson (2005).

${ }^{6}$ In Section 3.3 we expand the set of words associated with expansionary and contractionary policies and construct an alternative communication measure. Results are qualitatively unchanged.

7 Our script accounts for negative modifiers. For example, the term "not dovish" in a relevant sentence is counted as "hawkish". In addition, our script follows Lucca and Trebbi (2011) in excluding sentences that include the past tense of certain keywords. For example, a sentence containing "decided to tighten" would be excluded. This helps to remove discussions about past policy action.

${ }^{8}$ Note that even when we consider the same keywords and time sample as in Lucca and Trebbi (2011), our FSO measure may be different. One reason is that articles on Factiva are continuously updated, and so our sample of news outlets may be different from theirs. In addition, differently from Lucca and Trebbi (2011), we add a count of 1 to the numerator and denominator to avoid dropping observations due to zeroes. Our results are qualitatively unchanged without this adjustment to the word counts.
} 
semantic-based measure of communication surprises, $\triangle F S O_{d}$, as:

$$
\Delta F S O_{d} \equiv \ln \left(\frac{1+H_{d}^{\text {Post }}}{1+D_{d}^{\text {Post }}}\right)-\ln \left(\frac{1+H_{d}^{\text {Pre }}}{1+D_{d}^{\text {Pre }}}\right)
$$

where the Pre superscript indicates the sub-period of the three-day window that precedes the Fed announcement on communication date $d$, and the Post superscript indicates the sub-period after the announcement. Specifically, the Pre sub-period ranges from the start of the day before the announcement up to the time of the date- $d$ announcement. ${ }^{9}$ The Post sub-period starts at the time of the announcement and ends at the end of the following day. Hence, $H_{d}^{P r e}$ is the number of times the word "hawkish" appears in relevant sentences in articles that pre-date the announcement, $D_{d}^{P r e}$ is the number of times the word "dovish" appears in relevant sentences in the same set of articles, and analogously for variables with the Post superscript. ${ }^{10}$ In short, the semantic-based measure of communication surprise $C S_{d}$ used to estimate equation (1), $\Delta F S O_{d}$, is the difference between $F S O$ levels before and after a Fed communication event on date $d$.

Figure 1 reports FSO constructed using a three-day window around each communication date, along with its 6-period moving average and the Fed funds target rate. As in Lucca and Trebbi (2011), Figure 1 shows that, up to 2009, FSO leads the target federal funds rate by a few quarters. This pattern suggests that FSO captures information about future monetary policy. ${ }^{11}$ In Section 4 we provide additional evidence that this is indeed the case.

To measure interest rate surprises, we follow Kuttner (2001) and rely on federal funds futures contracts. For each communication date $d$, we measure the surprise as the change in the average effective federal funds rate implied by the current-month contract for the days remaining between the communication date $d$ and the end of the month. ${ }^{12}$ The implied rates are computed using

9 The timing of FOMC statement releases were obtained from Gürkaynak, Sack and Swanson (2005) for meetings between 1999 and 2004, from Lucca and Moench (2015) for meetings between 2005 and 2012, and from the Board of Governors for all other meetings. The timing of congressional testimonies is set at 12pm EST.

10 Following Lucca and Trebbi (2011), we weight each observation by the number of relevant sentences that underlie the observation. This helps improve the precision of our results, since it reduces the influence of dates with very few mentions of the Fed, which are likely to have greater measurement error.

11 Note that Figure 1 reports $F S O$ and not $\triangle F S O$, our measure of communication surprises. A picture of the latter, would look closer to i.i.d., and would not exhibit such low frequency movements as seen in $F S O$.

12 The calculation of the relevant rate implied by the current-month futures contract involves a "calendar adjustment" that takes into account when the communication date falls within the month. Federal funds futures contracts are settled based on the average effective federal funds rate that prevailed during the month of the contract. Therefore, the rate implied by the current-month contract on, say, the day before an FOMC meeting is a weighted average of the prevailing rate up to that day and the rate that is expected to hold from the FOMC date until the end of the month (risk premia aside). Because the contract is based on a monthly average, the day of the month of each announcement matters. Hence, in order to estimate the change in the rate implied for the remainder of the month, the change in the rate implied by the futures contract for the whole month is weighted by the inverse of the share of remaining days in the total number of days in the month. For FOMC meetings that fall in the last seven days of a month, we use the (unscaled) change in the rate implied by the next futures contract. For further details, see Kuttner (2001) and Gürkaynak, Sack and Swanson (2005). 
Figure 1: The measure of Fed communication $\triangle F S O$ and the fed funds target rate

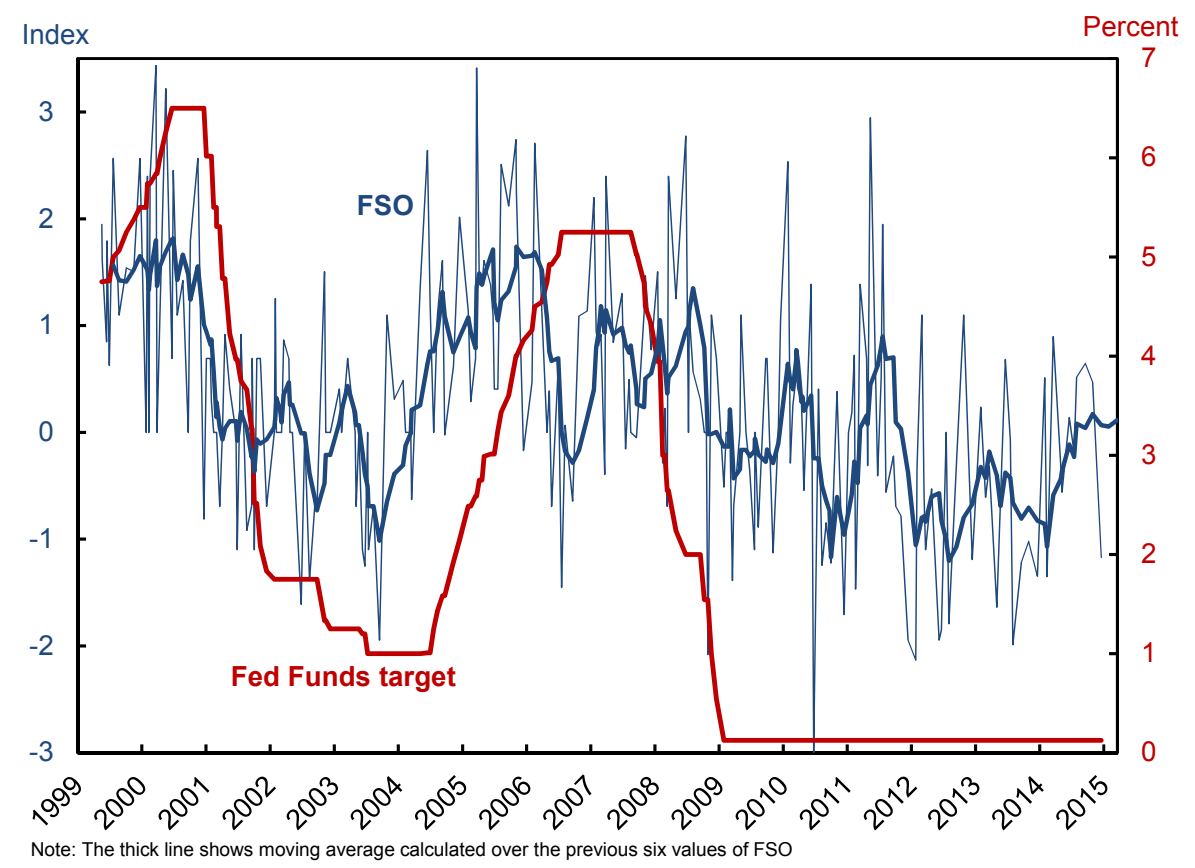

Note: FSO corresponds to the ratio of the number of times the word "hawkish" appears in relevant sentences of a set of news articles to the number of times the word "dovish" appears in the same set of articles within a three-day window around each communication date. See Section 2 for a detailed description.

end-of-day quotes for the day of and the day before the communication event. This measure of interest rate surprises is often referred to as "Kuttner surprises." The Appendix Figure A1 reports the Kuttner surprises.

\section{The effect of the ZLB on monetary policy}

\subsection{Baseline specification}

Our main results from the estimation of equation (1) are shown in Table 1. The table reports the effects of communication and monetary surprises on yields ranging from 3-months to 10-years during the pre-ZLB period (Panel A) and during the ZLB period (Panel B). Therefore, a comparison between Panels A and B uncovers the differences between the effects of Fed communication (and interest rate) surprises in the pre-ZLB and ZLB periods. Heteroskedasticity-consistent standard errors are reported throughout.

In the pre-ZLB sample, Fed communication significantly affects Treasury yields of all maturities from 6 months to 10 years. In contrast, the effects of Fed communication during the ZLB period are concentrated on longer-dated yields. In particular, the effects on yields of maturi- 
ties up to one year become statistically insignificant and/or decline substantially. Longer-dated yields, on the other hand, continue to respond to communication surprises. A statistical test for the equality of coefficients reported in Panels A and B confirms that the effects of communication on shorter-term yields have significantly changed across the two subsamples. Coefficients on longer-dated yields, however, are not statistically different from one another. Results are available upon request.

Table 1: Effects of the measure of Fed communication $\triangle F S O$ on yields

\begin{tabular}{|c|c|c|c|c|c|}
\hline \multicolumn{6}{|c|}{ Panel A: Pre-ZLB period } \\
\hline & \multicolumn{5}{|c|}{ Treasury yields: } \\
\hline Communication $(\beta)$ & $\begin{array}{c}3 \text {-month } \\
0.96 \\
(0.63)\end{array}$ & $\begin{array}{c}\text { 6-month } \\
1.36^{* * *} \\
(0.42)\end{array}$ & $\begin{array}{c}\text { 2-years } \\
3.13^{* * *} \\
(0.66)\end{array}$ & $\begin{array}{c}\text { 5-years } \\
2.99 * * * \\
(0.74)\end{array}$ & $\begin{array}{c}10 \text {-years } \\
2.08^{* * *} \\
(0.68)\end{array}$ \\
\hline Mon. Surprise $(\gamma)$ & $\begin{array}{c}0.59^{* * *} \\
(0.1)\end{array}$ & $\begin{array}{c}0.58^{* * *} \\
(0.06)\end{array}$ & $\begin{array}{c}0.38^{* * *} \\
(0.09)\end{array}$ & $\begin{array}{c}0.24^{*} \\
(0.12)\end{array}$ & $\begin{array}{c}0.12 \\
(0.12)\end{array}$ \\
\hline$R^{2}$ & 0.55 & 0.58 & 0.36 & 0.22 & 0.12 \\
\hline Observations & 151 & 151 & 151 & 151 & 151 \\
\hline \multicolumn{6}{|c|}{ Panel B: ZLB period } \\
\hline & \multicolumn{5}{|c|}{ Treasury yields: } \\
\hline Communication $(\beta)$ & $\begin{array}{c}3 \text {-month } \\
0.05 \\
(0.06)\end{array}$ & $\begin{array}{c}\text { 6-month } \\
0.24^{* * *} \\
(0.08)\end{array}$ & $\begin{array}{c}\text { 2-years } \\
1.51^{* * *} \\
(0.43)\end{array}$ & $\begin{array}{c}5 \text {-years } \\
2.80^{* * *} \\
(0.93)\end{array}$ & $\begin{array}{c}10 \text {-years } \\
2.20^{* *} \\
(0.88)\end{array}$ \\
\hline Mon. Surprise $(\gamma)$ & $\begin{array}{c}0.16^{* * *} \\
(0.02)\end{array}$ & $\begin{array}{c}-0.13^{* * *} \\
(0.03)\end{array}$ & $\begin{array}{c}0.92^{* * *} \\
(0.16)\end{array}$ & $\begin{array}{c}1.90^{* * *} \\
(0.34)\end{array}$ & $\begin{array}{c}2.31^{* * *} \\
(0.27)\end{array}$ \\
\hline$R^{2}$ & 0.1 & 0.15 & 0.3 & 0.28 & 0.27 \\
\hline Observations & 89 & 89 & 89 & 89 & 89 \\
\hline
\end{tabular}

Note: The table provides results for the estimation of $\Delta y_{d}^{m}=\alpha^{m}+\beta^{m} C S_{d}+\gamma^{m} M S_{d}+\varepsilon_{d}^{m}$, where $\Delta y_{d}^{m}$ is the change in Treasury yields of bonds with maturity $m$ around a "communication date" $d, C S_{d}$ measures communication surprises using $\triangle F S O$, and $M S_{d}$ measures interest rate surprises using Kuttner surprises around a date $d$. Communication dates are those of FOMC statement releases and dates of testimonies by the Chair of the Federal Reserve Board. The pre-ZLB sample goes from May 18, 1999 to December 15, 2008. The ZLB period goes from December 16, 2008 to December 17, 2014. Details about measures of communication and interest rate surprises are provided in Section 2. Heteroskedasticity-consistent standard errors are reported in parentheses. Coefficients followed by ${ }^{* * *},{ }^{* *}$, or ${ }^{*}$ are statistically significant at the $1 \%, 5 \%$, or $10 \%$ levels, respectively.

The regression coefficients in Table 1 also suggest that the effects of Fed communication on longer-dated yields continue to be non-trivial during the ZLB period. The standard deviation of Fed communication surprises $(\triangle F S O)$ in the pre-ZLB and ZLB periods are 1.1 and 1.3 basis 
points, respectively. These imply that, in response to a one-standard deviation Fed communication surprise, 10-year Treasury yields, for example, change by 2.3 basis points in the pre-ZLB period and by and 2.5 basis points during the ZLB period. In what follows all coefficients can be interpreted in the same manner.

Figure 2: Effects of the measure of Fed communication $\triangle F S O$ on yields over time: rolling regressions
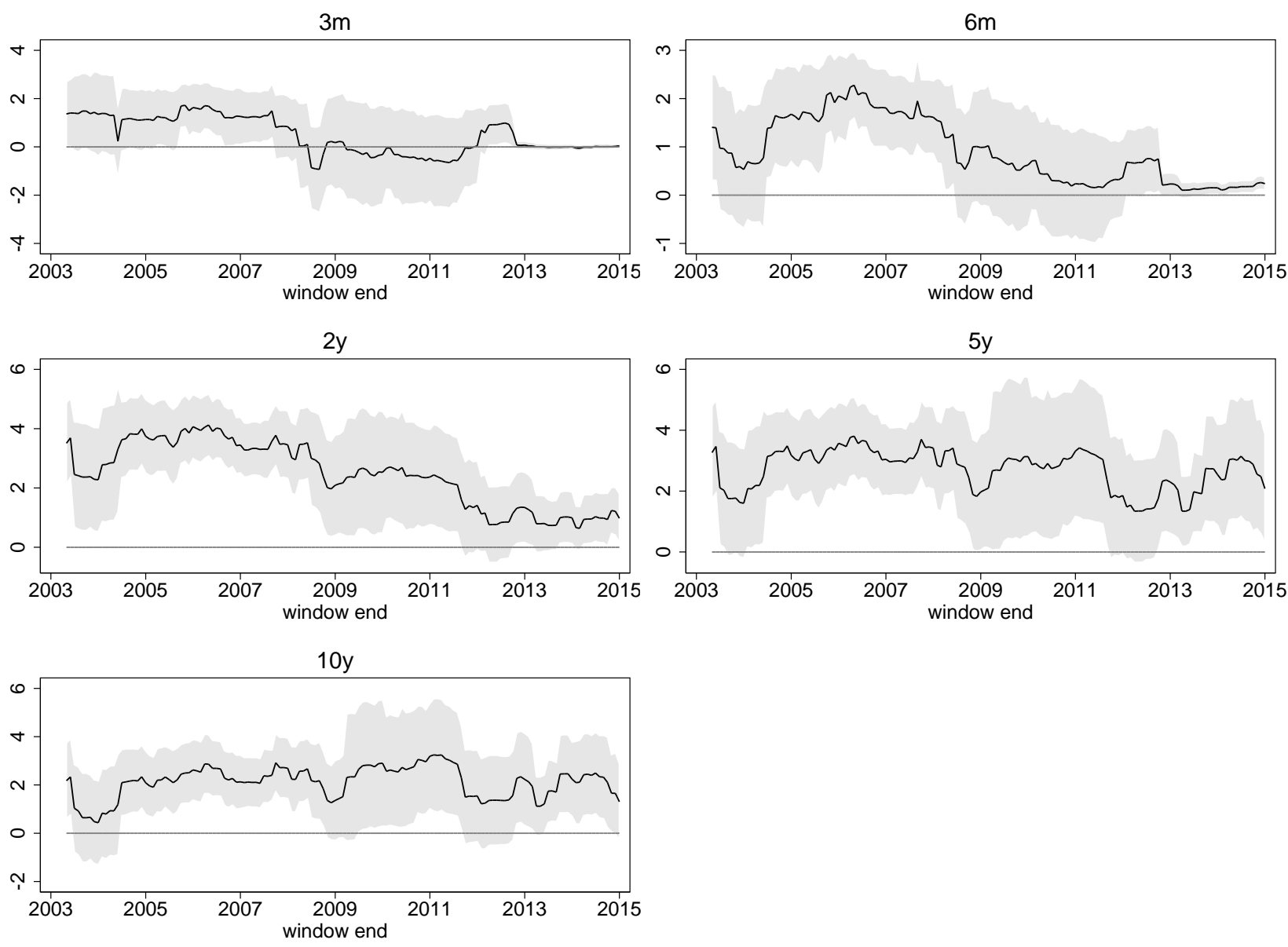

Note: The figure shows the effects of the semantic-based measure of communication $(\triangle F S O)$ resulting from the estimation of the regression $\Delta y_{d}^{m}=\alpha^{m}+\beta^{m} C S_{d}+\gamma^{m} M S_{d}+\varepsilon_{d}^{m}$, over rolling windows of 48 months. $\Delta y_{d}^{m}$ is the change in Treasury yields of bonds with maturity $m$ around a "communication date" $d, C S_{d}$ measures communication surprises using $\triangle F S O$, and $M S_{d}$ measures interest rate surprises using Kuttner surprises around a date $d$. Communication dates are those of FOMC statement releases and dates of testimonies by the Chair of the Federal Reserve Board. Details about measures of communication and interest rate surprises are provided in Section 2. The shaded regions represent $90 \%$ confidence intervals based on heteroskedastic-consistent standard errors.

Panels A and B in Table 1 also show that the coefficients on the monetary surprise are statistically significant in both the pre- and the ZLB periods. While the statistical significance during the pre-ZLB period is as expected, the results during the ZLB period may seem odd, 
since during that time there were no changes to the policy rate. Indeed, during the ZLB period, the monetary surprises series is much smaller in levels and variation, relative to the series during the pre-ZLB period (see Appendix Figure A1). We view these coefficients during the ZLB period as not economically meaningful, despite the statistical significance. Confirming this conjecture, in unreported results we excluded the Kuttner surprises from regressions using data from the ZLB period and results are qualitatively unchanged. Throughout the paper, for symmetry, we chose to keep the monetary surprises in all regressions.

To further analyze how the effects of Fed communication changed over time, we estimate regression (1) over rolling windows of 48 months each. Figure 2 summarizes the results by reporting the "path" of estimated $\beta^{m}$ coefficients for the measure of communication surprises $(\triangle F S O)$. The shaded regions represent $90 \%$ confidence intervals based on heteroskedasticityconsistent standard errors. Note that, because we use windows of 48 months from May 1999 to December 2014, for regressions estimated using data starting in 2009 (with windows ending in 2013 and later), only communication dates in the ZLB period are included.

Concurring with the results of Table 1, Figure 2 shows that, as more ZLB dates are added to the sample, the response of 3- and 6-month yields to communication surprises drop to near zero. The estimated coefficients of longer-term yields, particularly 5- and 10-year yields, are basically unchanged. We note, however, an increase in the volatility of the sensitivity of the response of longer-term yields to communication surprises, evidenced by the relative widening of their confidence intervals as ZLB dates are added to the sample.

Note that these patterns across different maturities resemble those obtained by Swanson and Williams (2014). The authors estimate the effects of macroeconomic news on short- and long-term yields using rolling regressions. Similarly to the patterns reported in the panels of Figure 2, they find that longer-dated yields continue to respond to macroeconomic news, even as more and more ZLB observations enter the rolling sample. In contrast, the coefficients of shorter-term yields drop to near zero.

Overall, our results are consistent with the idea that, despite the constraint on the Fed's ability to influence short-term yields during the ZLB period, communication continued to allow the Fed to affect longer-term yields.

\subsection{Intraday data}

At times, the literature has highlighted the benefits of using intraday data for this type of analysis, in order to avoid confounding effects from other data releases during the communication dates (e.g., Rudebusch 1998, Bernanke and Kuttner 2005, and Gürkaynak, Sack and Swanson 2005). 
However, since 1995, FOMC statement releases do not coincide with major macroeconomic data releases. Since our sample starts in 1999, using intraday instead of daily data is unlikely to make a meaningful difference for our results. Nevertheless, to complement our analysis, in this section we estimate the effects of communication and interest rate surprises on Treasury yields using intraday data.

To that end, we constrain our sample to FOMC statement release dates only. ${ }^{13}$ We construct intraday Kuttner surprises using changes in fed funds futures quotes within a window ranging from 10 minutes before to 20 minutes after the FOMC statement release. ${ }^{14}$ In a similar manner, we calculate intraday changes in Treasury yields with maturities of 2,5 , and 10 years. ${ }^{15}$

Table 2 presents the results based on intraday data. The first thing to notice is that once testimonies are excluded from the sample, the number of observations in each regression drops substantially, particularly during the ZLB period. Despite the limited sample, the results reported in Table 2 resemble those of Table 1. During the ZLB period, communication (as measured by $\triangle F S O$ ) continued to affect longer-dated yields, whereas its effects on the shorter-dated ones (2-year, in this case) became more muted. ${ }^{16}$

\subsection{FSO based on alternative set of keywords}

In building FSO, we only considered "hawkish" and "dovish" as words that can characterize policy. Arguably, other sets of words could also be considered. One downside of expanding the set of words is that this may introduce noise in our measurement. While some keywords may be used to describe policy during one period of time, they may not be so relevant in others. For example, during the pre-ZLB period, expansionary policies could be associated with words related to declines in the policy rate, such as cut, decrease or loose. During the ZLB period, however, these words would most likely add noise to our semantic measure, since the federal funds rate target was already constrained by the ZLB.

Despite these caveats, in this subsection we consider an expanded set of words and build an alternative semantic measure of Fed communication, $F S O_{\text {alt }}$. In particular, we associate contractionary policies with the set $\{$ hawkish, tighten $\}$, and expansionary policies with the set $\{$ dovish, ease $\}$.

\footnotetext{
${ }^{13}$ We thank Eric Swanson for providing us with intraday data on federal funds futures through June 2013. The remaining intraday data for Fed funds futures and Treasury yields are obtained from Tick Data. Due to data limitations, we use Treasury yields implied by Treasury futures quotes.

${ }^{14}$ In unreported results, we also consider windows ranging from 15 minutes before to 45 minutes after the announcement. Our results are qualitatively unchanged.

15 Unfortunately we do not have intraday data for the 3-month and 6-month maturities.

${ }^{16}$ For completeness, the Appendix Table A2 reports results using daily data when the sample is constrained to include FOMC statement dates only.
} 
Table 2: Effects of the measure of Fed communication $\triangle F S O$ on yields using intraday data

\begin{tabular}{|c|c|c|c|}
\hline \multicolumn{4}{|c|}{ Panel A: Pre-ZLB period } \\
\hline & \multicolumn{3}{|c|}{ Treasury yields } \\
\hline \multirow{3}{*}{ Communication $(\beta)$} & 2-years & 5-years & 10-years \\
\hline & $1.22^{* *}$ & $1.40^{* *}$ & $0.98^{* *}$ \\
\hline & $(0.54)$ & $(0.6)$ & $(0.46)$ \\
\hline \multirow[t]{2}{*}{ Mon. Surprise $(\gamma)$} & $0.18^{*}$ & 0.10 & 0.01 \\
\hline & $(0.1)$ & $(0.08)$ & $(0.05)$ \\
\hline \multirow{2}{*}{$\begin{array}{l}R^{2} \\
\text { Observations }\end{array}$} & 0.17 & 0.13 & 0.09 \\
\hline & 81 & 81 & 81 \\
\hline \multicolumn{4}{|c|}{ Panel B: ZLB period } \\
\hline \multirow{4}{*}{ Communication $(\beta)$} & \multicolumn{3}{|c|}{ Treasury yields: } \\
\hline & 2-years & 5-years & 10-years \\
\hline & 0.63 & $1.43^{*}$ & $1.30^{*}$ \\
\hline & $(0.43)$ & $(0.8)$ & $(0.66)$ \\
\hline \multirow[t]{2}{*}{ Mon. Surprise $(\gamma)$} & $0.76^{* * *}$ & $0.72^{* * *}$ & $0.74^{* * *}$ \\
\hline & $(0.03)$ & $(0.1)$ & $(0.09)$ \\
\hline$R^{2}$ & 0.45 & 0.23 & 0.19 \\
\hline Observations & 48 & 48 & 48 \\
\hline
\end{tabular}

Note: The table provides results for the estimation of $\Delta y_{d}^{m}=\alpha^{m}+\beta^{m} C S_{d}+\gamma^{m} M S_{d}+\varepsilon_{d}^{m}$, where $\Delta y_{d}^{m}$ is the change in Treasury yields of bonds with maturity $m$ around a "communication date" $d$. $C S_{d}$ measures communication surprises using $\triangle F S O$, and $M S_{d}$ measures interest rate surprises using Kuttner surprises around a date $d$. Communication dates are those of FOMC statement releases only. The pre-ZLB sample goes from May 18, 1999 to December 15, 2008. The ZLB period goes from December 16, 2008 to December 17, 2014. Details about measures of communication and interest rate surprises are provided in Sections 2 and 3. Heteroskedasticityconsistent standard errors are reported in parentheses. Coefficients followed by ${ }^{* * *},{ }^{* *}$, or ${ }^{*}$ are statistically significant at the $1 \%, 5 \%$, or $10 \%$ levels, respectively.

Table 3 reports the main regression results when using $\triangle F S O_{\text {alt }}$ as a measure of Fed communication surprises, and shows that the patterns observed in Table 1 are unchanged. During the ZLB period, longer-term yields were still affected by Fed communication surprises, as measured by $\triangle F S O_{\text {alt }}$.

\section{Assessing our measure of communication}

Our analysis relies on an interpretation of $\triangle F S O$ as a measure of Fed communication surprises. Figure 1 shows that, up to 2009, FSO leads the fed funds target rate by a few quarters, suggesting it contains some information about future policy. 
Following up on this initial suggestive evidence, in this Section we further assess our measure of Fed communication in three different ways. First, we use our (limited) sample of intraday data to evaluate how yields respond to $\triangle F S O$ around short windows of time around the announcement. Next we consider an alternative measure of Fed communication in which we only include news articles released immediately after the FOMC statement release. These articles were most likely produced during the Fed news embargo, and therefore, are not affected by markets' response to the release. Finally, we rely on a dynamic term-structure model to evaluate how our measure of communication affects the risk-neutral and term-premium components of Treasury yields.

Table 3: Effects of the alternative measure of Fed communication $\Delta F S O_{\text {alt }}$ on yields

\begin{tabular}{|c|c|c|c|c|c|}
\hline \multicolumn{6}{|c|}{ Panel A: Pre-ZLB period } \\
\hline & \multicolumn{5}{|c|}{ Treasury yields: } \\
\hline & 3-month & 6-month & 2-years & 5-years & 10-years \\
\hline Communication $(\beta)$ & $\begin{array}{c}0.64 \\
(0.87)\end{array}$ & $\begin{array}{c}0.51 \\
(1.01)\end{array}$ & $\begin{array}{c}3.29 * * * \\
(1.1)\end{array}$ & $\begin{array}{c}3.37^{* * *} \\
(1.19)\end{array}$ & $\begin{array}{c}2.87^{* * * *} \\
(1.03)\end{array}$ \\
\hline Mon. Surprise $(\gamma)$ & $\begin{array}{c}0.60^{* * *} \\
(0.1)\end{array}$ & $\begin{array}{c}0.59 * * * \\
(0.06)\end{array}$ & $\begin{array}{c}0.40^{* * *} \\
(0.1)\end{array}$ & $\begin{array}{l}0.26^{*} \\
(0.13)\end{array}$ & $\begin{array}{c}0.13 \\
(0.12)\end{array}$ \\
\hline$R^{2}$ & 0.54 & 0.55 & 0.29 & 0.16 & 0.11 \\
\hline Observations & 151 & 151 & 151 & 151 & 151 \\
\hline \multicolumn{6}{|c|}{ Panel B: ZLB period } \\
\hline & \multicolumn{5}{|c|}{ Treasury yields: } \\
\hline Communication $(\beta)$ & $\begin{array}{c}\text { 3-month } \\
0.10 \\
(0.11)\end{array}$ & $\begin{array}{c}\text { 6-month } \\
0.42^{* * *} \\
(0.11)\end{array}$ & $\begin{array}{c}2 \text {-years } \\
1.57 * * * \\
(0.58)\end{array}$ & $\begin{array}{c}\text { 5-years } \\
2.70 * * \\
(1.15)\end{array}$ & $\begin{array}{c}10 \text {-years } \\
1.91^{*} \\
(1.08)\end{array}$ \\
\hline Mon. Surprise $(\gamma)$ & $\begin{array}{c}0.16^{* * *} \\
(0.02)\end{array}$ & $\begin{array}{c}-0.13^{* * *} \\
(0.03)\end{array}$ & $\begin{array}{c}0.94^{* * *} \\
(0.16)\end{array}$ & $\begin{array}{c}1.94^{* * *} \\
(0.36)\end{array}$ & $\begin{array}{c}2.34^{* * *} \\
(0.29)\end{array}$ \\
\hline$R^{2}$ & 0.10 & 0.19 & 0.22 & 0.20 & 0.21 \\
\hline Observations & 89 & 89 & 89 & 89 & 89 \\
\hline
\end{tabular}

Note: The table provides results for the estimation of $\Delta y_{d}^{m}=\alpha^{m}+\beta^{m} C S_{d}+\gamma^{m} M S_{d}+\varepsilon_{d}^{m}$, where $\Delta y_{d}^{m}$ is the change in Treasury yields of bonds with maturity $m$ around a "communication date" $d, C S_{d}$ measures communication surprises using $\triangle F S O_{\text {alt }}$, and $M S_{d}$ measures interest rate surprises using Kuttner surprises around a date $d$. Communication dates are those of FOMC statement releases and dates of testimonies by the Chair of the Federal Reserve Board. The pre-ZLB sample goes from May 18, 1999 to December 15, 2008. The ZLB period goes from December 16, 2008 to December 17, 2014. Details about measures of communication and interest rate surprises are provided in Sections 2 and 3. Heteroskedasticity-consistent standard errors are reported in parentheses. Coefficients followed by ${ }^{* * *},{ }^{* *}$, or ${ }^{*}$ are statistically significant at the $1 \%, 5 \%$, or $10 \%$ levels, respectively. 


\subsection{The effects of $\triangle F S O$ around announcement times}

As a first test, we reestimate equation (1) varying the 30-minute window over which the dependent variables $\left(\Delta y_{d}^{m}\right)$ are computed on days of FOMC statement releases. A 30-minute window around a time $t$ ranges from 10 minutes before to 20 minutes after $t$. Without loss of generality, for each FOMC statement release date, we set $t=0$ to be the time of the release. Hence, for all $t<-20 \mathrm{~min}$, the window ends strictly before the statements were released, whereas, for all $t>10 \mathrm{~min}$, the window starts strictly after the releases. Regressions for 30-minute windows around times $t=0$ replicate the results reported in Table 2 exactly. If $\triangle F S O$ indeed captures Fed communication surprises, the coefficients $\left(\beta^{m}\right)$ obtained by estimating equation (1) using 30-minute windows around a time $t$ should decrease as we increase $|t|$.

Figure 3 presents the results. They show estimated $\beta^{m}$ coefficients (from equation (1)), along with $90 \%$ confidence bands shaded in gray, for 2-, 5-, and 10-year yields, using 30-minute windows around different times $t$. All panels share a somewhat similar pattern. Near time $t=0$, the effects of both the semantic- and the yield-based measures of Fed communication surprises are largest and, in most cases, statistically significant. As the time windows are shifted away from the time of FOMC statement releases $(t=0)$, the estimated $\beta^{m}$ coefficients decline and/or become statistically insignificant. These results hold during both the pre- and the ZLB periods, giving additional credence to the interpretation that $\triangle F S O$ captures Fed communication surprises.

\subsection{Accounting for the Fed news embargo}

One possible concern with the construction of the measure of communication $\Delta F S O$ is that news articles might be shaped by market reactions to FOMC announcements. In that case, if news articles are just a reflection of movements in yields, our results may suffer from reverse causality.

To address these concerns, in this section we construct an alternative measure of $\Delta F S O$ that almost certainly only includes articles that are unaffected by market reactions. In particular, we construct an alternative measure of Fed communication surprises that restricts the sample to news articles that were, very likely, produced during the news embargo applied before the communication release.

News embargoes are commonly applied preceding important data releases and reports by the government, monetary authorities and other institutions across the world. The conditions are such that a few (previously selected) members of the press gain access to the information before its official release, under the agreement that their reports and news articles about the information will only be made public after the official release. 
Figure 3: Effects of the measure of Fed communication $\triangle F S O$ on yields outside announcement times
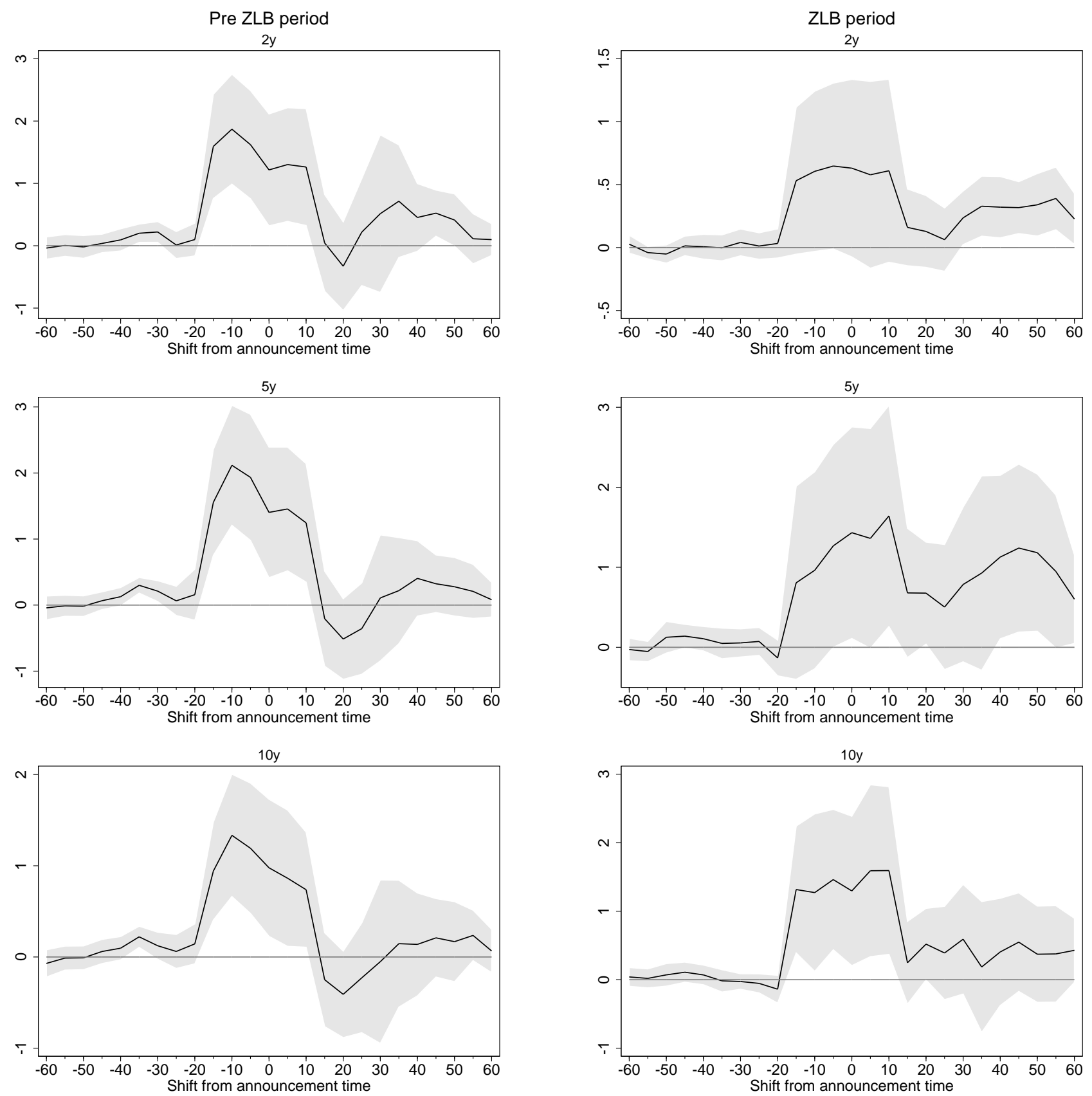

Note: The figure shows the effects of the semantic-based measure of communication $(\triangle F S O)$ resulting from the estimation of the regression $\Delta y_{d}^{m}=\alpha^{m}+\beta^{m} C S_{d}+\gamma^{m} M S_{d}+\varepsilon_{d}^{m}$, where $\Delta y_{d}^{m}$ is the change in Treasury yields of bonds with maturity $m$ around a "communication date" $d, C S_{d}$ measures communication surprises using $\Delta F S O$, and $M S_{d}$ measures interest rate surprises using Kuttner surprises around a date $d$. Communication dates are those of FOMC statement releases. $\Delta y_{d}^{m}$ are calculated within a 30-minute windows from 1 hour before to one hour after FOMC statement releases. Time 0 in each panel marks the announcement time. Details about measures of communication and interest rate surprises are provided in Section 2. Details about this exercise are provided in Section 4. The shaded regions represent $90 \%$ confidence intervals based on heteroskedastic-consistent standard errors. 
Similarly to other important economic releases, FOMC statements and the Chair's speech preceding testimonies are provided to reporters in secured lockups before being released to the public. While in lockup, members of the press have time to read and prepare their reports about the release. More importantly, reporters are completely prohibited from communication with the outside world. Therefore, news articles that are released immediately after the FOMC statement release are not affected by markets' reaction to the communication release as they were produced during the lockup.

Unfortunately, the members of the press that participate in the embargo are not publicly known, and hence, we cannot simply set aside articles produced by specific reporters. In addition, it is also not public information how much time reporters have to produce their pieces nor how this procedure has evolved over time. ${ }^{17}$ To get around these limitations, we consider using only the set of articles that were released within a short window after the FOMC statement release.

Of course, limiting the set of articles to those released as close as possible to the statement release would be preferable. However, this could imply a very limited set of articles, adding noise to our measure of Fed communication. During the ZLB period, for example, our dataset contains an average of 7 articles released within one minute of the FOMC statement release. This average increases to 14 and 23 when considering windows of 5 and 10 minutes after the announcement, respectively. These numbers are quite small relative to the average number of articles used to construct the benchmark $\triangle F S O$ of Section 2, which averages around $470 .{ }^{18}$

Taking all that into account, we construct an alternative measure of Fed communication surprises that limits the set of "post" news articles to only include those published within 5 minutes of the FOMC statement release time. In particular, we build $\triangle F S O^{5 m i n}$ which is calculated as in $\triangle F S O$ in equation (2), except that the "Post" articles (and the corresponding relevant sentences) include only those released up to 5 minutes after the FOMC statement releases. ${ }^{19}$ Results are reported on Table 4.

Panel B of Table 4 shows that the results during the ZLB period are qualitatively unchanged, i.e., communication effects concentrate on longer-dated yields. Note that during the pre-ZLB period, none of the coefficients are statistically significant. For this exercise, however, the limited set or articles in addition to the set of words associated with hawkish and dovish policies may be the driver of these results. Recall that, as discussed in Section 3.3, during the pre-ZLB period,

\footnotetext{
${ }^{17}$ In conversations with a member of the Federal Reserve Board's Public Affairs Office we were informed that the use of news embargo has been in place since the 1990s and that the time spent by reporters in the lockup is enough for them to "read, digest and produce their reports." The embargo and release of testimonies, are under the control of the government, not the Federal Reserve.

18 Not all articles in the Factiva data base contain the time of release, which further constrains the sample of articles we can use for this exercise.

${ }^{19}$ We also constructed $\triangle F S O$ using articles released within 10 and 15 minutes of the Fed announcement. Results are qualitatively similar and available upon request.
} 
words such as "ease" or "tighten" may be more representative of the actions of the Fed. To test for this conjecture, we construct $\triangle F S O_{a l t}^{5 m i n}$ in analogy to $\triangle F S O^{5 m i n}$ but including "ease" or "tighten" in the set of dovish and hawkish words, respectively. We find that for this case, the coefficients on $\triangle F S O_{\text {alt }}^{5 \min }$ are statistically significant for short-term maturities. Results are available upon request.

Table 4: Effects of the measure of Fed communication $\triangle F S O^{5 m i n}$ on yields

\begin{tabular}{|c|c|c|c|c|c|}
\hline \multicolumn{6}{|c|}{ Panel A: Pre-ZLB period } \\
\hline & \multicolumn{5}{|c|}{ Treasury yields: } \\
\hline Communication $(\beta)$ & $\begin{array}{c}\text { 3-month } \\
0.03 \\
(0.71)\end{array}$ & $\begin{array}{c}\text { 6-month } \\
-0.14 \\
(0.69)\end{array}$ & $\begin{array}{c}\text { 2-years } \\
1.02 \\
(0.93)\end{array}$ & $\begin{array}{c}\text { 5-years } \\
0.95 \\
(0.95)\end{array}$ & $\begin{array}{c}\text { 10-years } \\
0.85 \\
(0.77)\end{array}$ \\
\hline Mon. Surprise $(\gamma)$ & $\begin{array}{c}0.55^{* * *} \\
(0.17)\end{array}$ & $\begin{array}{c}0.62^{* * *} \\
(0.11)\end{array}$ & $\begin{array}{c}0.51^{* * *} \\
(0.19)\end{array}$ & $\begin{array}{c}0.29 \\
(0.21)\end{array}$ & $\begin{array}{c}0.15 \\
(0.17)\end{array}$ \\
\hline$R^{2}$ & 0.31 & 0.39 & 0.18 & 0.07 & 0.04 \\
\hline Observations & 84 & 84 & 84 & 84 & 84 \\
\hline \multicolumn{6}{|c|}{ Panel B: ZLB period } \\
\hline & \multicolumn{5}{|c|}{ Treasury yields: } \\
\hline Communication $(\beta)$ & $\begin{array}{c}\text { 3-month } \\
0.08 \\
(0.13)\end{array}$ & $\begin{array}{c}\text { 6-month } \\
0.22^{* *} \\
(0.1)\end{array}$ & $\begin{array}{c}\text { 2-years } \\
1.35^{* *} \\
(0.62)\end{array}$ & $\begin{array}{c}\text { 5-years } \\
3.11^{* *} \\
(1.45)\end{array}$ & $\begin{array}{c}10 \text {-years } \\
2.47^{*} \\
(1.27)\end{array}$ \\
\hline Mon. Surprise $(\gamma)$ & $\begin{array}{c}0.15^{* * *} \\
(0.03)\end{array}$ & $\begin{array}{c}-0.14^{* * *} \\
(0.04)\end{array}$ & $\begin{array}{c}0.85^{* * *} \\
(0.17)\end{array}$ & $\begin{array}{c}1.76^{* * *} \\
(0.47)\end{array}$ & $\begin{array}{c}2.17^{* * *} \\
(0.37)\end{array}$ \\
\hline$R^{2}$ & 0.1 & 0.11 & 0.22 & 0.23 & 0.25 \\
\hline Observations & 49 & 49 & 49 & 49 & 49 \\
\hline
\end{tabular}

Note: The table provides results for the estimation of $\Delta y_{d}^{m}=\alpha^{m}+\beta^{m} C S_{d}+\gamma^{m} M S_{d}+\varepsilon_{d}^{m}$, where $\Delta y_{d}^{m}$ is the change in Treasury yields of bonds with maturity $m$ around a "communication date" $d, C S_{d}$ measures communication surprises using $\triangle F S O^{5 m i n}$, and $M S_{d}$ measures interest rate surprises using Kuttner surprises around a date $d$. This measure of communication only uses articles published up to 5 minutes after the FOMC statement release. Communication dates are those of FOMC statement releases. The pre-ZLB sample goes from May 18, 1999 to December 15, 2008. The ZLB period goes from December 16, 2008 to December 17, 2014. Details about measures of communication and interest rate surprises are provided in Sections 2 and 4.2. Heteroskedasticity-consistent standard errors are reported in parentheses. Coefficients followed by ${ }^{* * *},{ }^{* *}$, or * are statistically significant at the $1 \%, 5 \%$, or $10 \%$ levels, respectively. 


\subsection{Yield decomposition}

Finally, to better understand what drives the effects of communication on yields, we use a decomposition of yields based on a no-arbitrage affine dynamic term-structure model. In particular, we use the shadow-rate dynamic term-structure model proposed by Christensen and Rudebusch (2016), which allows for a decomposition of nominal Treasury yields into its risk-neutral and term-premium components, while taking into account the constraints imposed by the zero lower bound on interest rates. ${ }^{20}$

We consider how these two components of yields respond to $\triangle F S O$ during the pre- and the ZLB periods. In particular, we reestimate our regressions while having the risk-neutral and the term-premium components of 3-month to 10-year yields as the dependent variables. Table 5 reports results. The left-hand-side of Table 5 shows the estimated effects of $\triangle F S O$ on the risk-neutral component, while the right-hand-side shows the estimated effects of $\triangle F S O$ on the risk-premium component of Treasury yields.

A comparison between the two sets of regressions show that during both the pre- and the ZLB periods, $\triangle F S O$ affects yields only through their risk-neutral component, as the coefficients on the term-premium component are largely insignificant. For completeness, we also reestimate our rolling regressions having as dependent variables the risk-neutral and the term-premium components of yields. Figure A3 in the Appendix reports the results and confirms that $\triangle F S O$ affects yields through their risk-neutral component.

\section{A yield-based measure of communication}

Gürkaynak, Sack and Swanson (2005), and more recently, Swanson (2015) consider an alternative methodology to obtain a measure of Fed communication, which entails extracting a Fed communication factor from a set of short-term yields. In particular, Gürkaynak, Sack and Swanson (2005) extract a "target" and a "path" factor and use these factors as measures of interest rate and Fed communication surprises, respectively. In contrast, Swanson (2015) notes that asset purchases were also used as a monetary policy tool during the ZLB period. He considers a set of yields ranging from one month to seven quarters ahead, from which he extracts two factors, that are interpreted as measures of forward guidance and asset purchases surprises.

To complement our analysis, we implement their empirical approach using our daily data on yields. Because we want to compare the effects of Fed forward guidance communication before

\footnotetext{
${ }^{20}$ We thank Jens Christensen for kindly updating and sharing their model decomposition results. We note that the authors use "off-the-run" Treasury yields, while throughout this paper, we use "on-the-run" Treasury yields, which are more liquid, and hence, likely more sensitive to communication or interest rate surprises. Our results are qualitatively unchanged when "off-the-run" yields are used.
} 


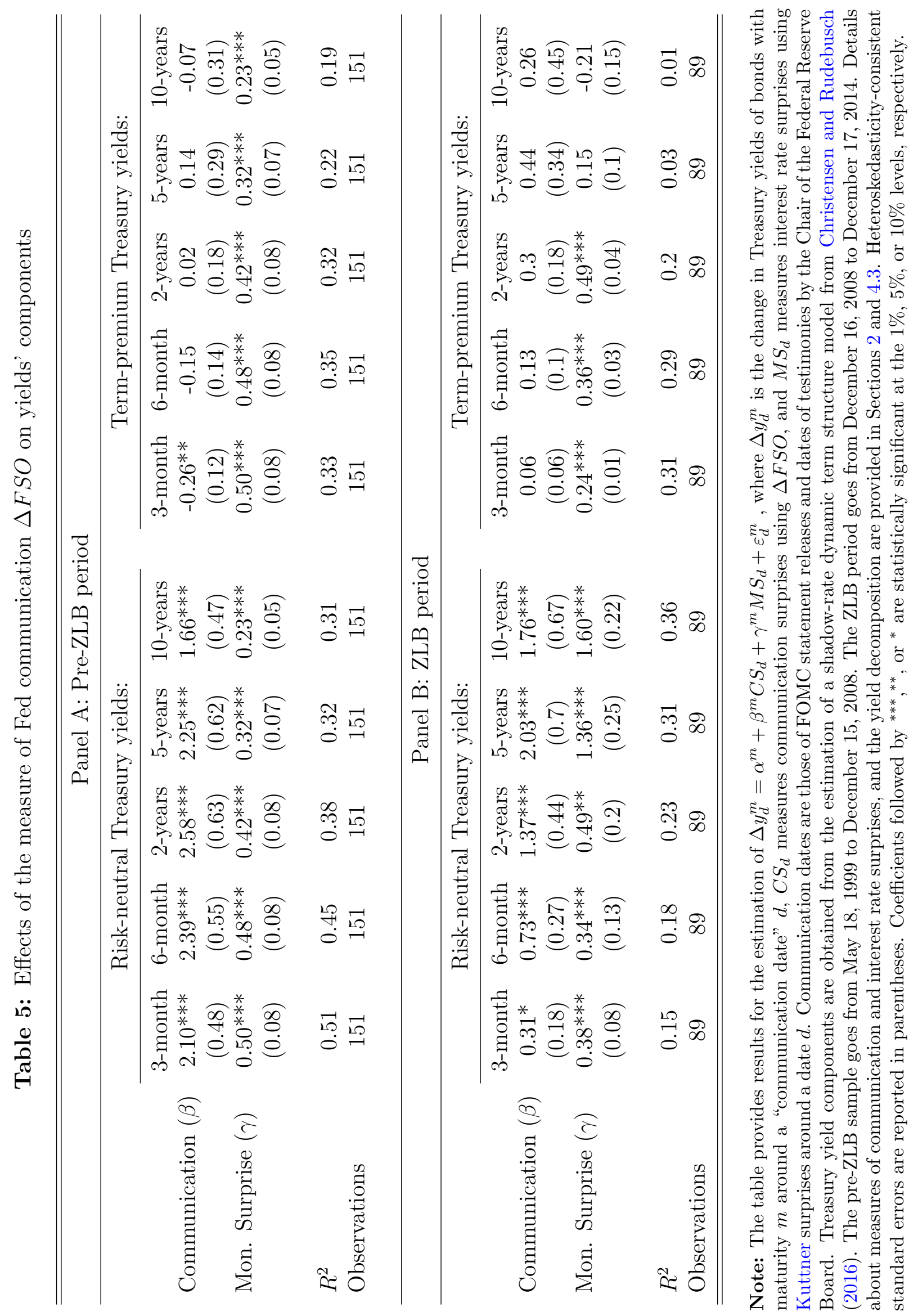


and during the ZLB, we implement a mix of these two approaches. As in Gürkaynak, Sack and Swanson (2005) we extract a "target" and a "path" factor from a set of short-term yields. We use these factors as measures of interest rate and Fed communication surprises, and "let the data speak" on the role of the target factor during the ZLB.

However, guided by Swanson (2015), we constrain the sample of dates from which we extract our two factors to exclude dates of LSAP-related announcements, which should bring us closer to Swanson (2015)'s forward guidance factor. In particular, we exclude every date in which the statement provides information about a new, or changes to, asset purchase programs. In addition, we also exclude the Chair's testimony to Congress of May 22, 2013 and the following FOMC statement released on June 19, 2013. Those dates are frequently referenced as the first time the Federal Reserve discussed its intention to scale back its asset purchase program, and are associated with a surge in U.S. treasury yields (the so-called "taper tantrum"). The Appendix Table A1 lists all LSAP-related dates.

Turning to the details, after excluding all LSAP-related dates, we assemble a matrix containing five series of changes in short-term yields for each of the 221 communication dates in our restricted sample. The first two series of this matrix are the (scaled) yield changes implied by federal funds futures contracts for the current-month (Kuttner surprises) and for the month containing the next FOMC meeting. ${ }^{21}$ The set of series also includes changes in yields implied by the price of Eurodollar futures contracts, which should be informative of revisions to expectations about short-term (in particular, 3-month) interest rates, 1-3 quarters in the future. These five series provide information about the effect of Fed communication on market expectations about the path of short-term rates up to approximately one year into the future.

We extract two principal components from the matrix of short-term yields. ${ }^{22,23}$ We then rotate these two principal components so that the two factors are orthogonal to one another, and that the second factor is orthogonal to the first series in the matrix (the Kuttner surprises). ${ }^{24}$

The first rotated factor $\left(Z_{1}\right)$ is highly correlated with the Kuttner surprises (0.999 correlation), and can be interpreted as interest rate surprises. Thus, for this yield-based estimation of equation (1), we use the target factor $Z_{1}$ as the measure of interest rate surprises $M S_{d}$. The

${ }^{21}$ The scaling of rates for contracts of months containing the next FOMC meeting is similar to the scaling of current-month contracts described in Footnote 12.

${ }^{22}$ The Cragg and Donald (1997) rank test points towards two components to characterize this matrix. We note, however, that this finding is dependent on the time sample and the data frequency (daily or intraday) used to extract the factors. Results using daily data suggest that an additional factor should be included. When we do so, however, this factor has little role in explaining yields, and hence, we opt to focus on only two factors.

${ }^{23}$ We entertained an alternative approach in which principal components are extracted separately for the pre-ZLB and ZLB subsamples. Results are qualitatively similar.

${ }^{24}$ As in Gürkaynak, Sack and Swanson (2005), we normalize the factors such that: (1) a unit change in $Z_{1}$ corresponds to a surprise 1 basis point change in the federal funds rate, and (2) $Z_{2}$ 's effect on 4-quarter-ahead Eurodollar futures (the 3rd back contract) is the same as $Z_{1}$ 's. 
other factor $Z_{2}$ captures other dimensions of monetary policy that are unrelated to interest rate surprises. ${ }^{25}$ For the yield-based estimation of equation (1), we use $Z_{2}$ as a measure of communication surprises $C S_{d}{ }^{26}$

Table 6: Effects of the yield-based measure of Fed communication $\left(Z_{2}\right)$ on yields

\begin{tabular}{|c|c|c|c|c|c|}
\hline \multicolumn{6}{|c|}{ Panel A: Pre-ZLB period } \\
\hline & \multicolumn{5}{|c|}{ Treasury yields: } \\
\hline Communication $(\beta)$ & $\begin{array}{c}\text { 3-month } \\
0.06^{* * *} \\
(0.02)\end{array}$ & $\begin{array}{c}\text { 6-month } \\
0.11^{* * *} \\
(0.02)\end{array}$ & $\begin{array}{c}\text { 2-years } \\
0.24^{* * *} \\
(0.01)\end{array}$ & $\begin{array}{c}\text { 5-years } \\
0.24^{* * *} \\
(0.02)\end{array}$ & $\begin{array}{c}\text { 10-years } \\
0.19^{* * *} \\
(0.02)\end{array}$ \\
\hline Mon. Surprise $(\gamma)$ & $\begin{array}{c}0.57^{* * *} \\
(0.11)\end{array}$ & $\begin{array}{c}0.53^{* * *} \\
(0.07)\end{array}$ & $\begin{array}{c}0.35^{* * *} \\
(0.05)\end{array}$ & $\begin{array}{c}0.20^{* *} \\
(0.09)\end{array}$ & $\begin{array}{c}0.10 \\
(0.08)\end{array}$ \\
\hline $\begin{array}{l}R^{2} \\
\text { Observations }\end{array}$ & $\begin{array}{c}0.47 \\
151\end{array}$ & $\begin{array}{c}0.59 \\
151\end{array}$ & $\begin{array}{c}0.83 \\
151\end{array}$ & $\begin{array}{l}0.7 \\
151\end{array}$ & $\begin{array}{c}0.56 \\
151\end{array}$ \\
\hline \multicolumn{6}{|c|}{ Panel B: ZLB period } \\
\hline & \multicolumn{5}{|c|}{ Treasury yields: } \\
\hline Communication $(\beta)$ & $\begin{array}{c}3 \text {-month } \\
0.04^{* * *} \\
(0.01)\end{array}$ & $\begin{array}{c}\text { 6-month } \\
0.03^{* *} \\
(0.01)\end{array}$ & $\begin{array}{c}\text { 2-years } \\
0.13^{* * *} \\
(0.04)\end{array}$ & $\begin{array}{c}\text { 5-years } \\
0.17^{* *} \\
(0.08)\end{array}$ & $\begin{array}{c}\text { 10-years } \\
0.14^{*} \\
(0.07)\end{array}$ \\
\hline Mon. Surprise $(\gamma)$ & $\begin{array}{l}0.72^{*} \\
(0.37)\end{array}$ & $\begin{array}{l}0.07 \\
(0.4)\end{array}$ & $\begin{array}{c}-3.28^{* * *} \\
(1.09)\end{array}$ & $\begin{array}{c}-5.27^{* * *} \\
(1.81)\end{array}$ & $\begin{array}{c}-5.12^{* * *} \\
(1.6)\end{array}$ \\
\hline$R^{2}$ & 0.19 & 0.12 & 0.43 & 0.35 & 0.3 \\
\hline Observations & 69 & 69 & 69 & 69 & 69 \\
\hline
\end{tabular}

Note: This table provides results for the estimation of $\Delta y_{d}^{m}=\alpha^{m}+\beta^{m} C S_{d}+\gamma^{m} M S_{d}+\varepsilon_{d}^{m}$, where $\Delta y_{d}^{m}$ is the change in Treasury yields of bonds with maturity $m$ around a "communication date" $d$. $C S_{d}$ measures communication surprises using $Z_{2}$, and $M S_{d}$ measures interest rate surprises using Kuttner surprises around a date $d$. Communication dates are those of FOMC statement releases and dates of testimonies by the Chair of the Federal Reserve Board, excluding dates of LSAPs announcements as listed in the Appendix Table A1. The pre-ZLB sample goes from May 18, 1999 to December 15, 2008. The ZLB period goes from December 16, 2008 to December 17, 2014. Details about measures of communication and interest rate surprises are provided in Section 5. Heteroskedasticity-consistent standard errors are reported in parentheses. Coefficients followed by ${ }^{* * *}$,** or * are statistically significant at the $1 \%, 5 \%$, or $10 \%$ levels, respectively.

Table 6 reports the results. Despite the different sources and methodologies applied to obtain the two measures of communication, the results reported in Tables 1 and 6 are qualitatively similar. During the ZLB period, the sensitivity of short-term yields declines, and the effects of

\footnotetext{
${ }^{25}$ Appendix Figure A1 reports the two factors.

${ }^{26}$ Despite the differences in methodology and data, we note that Swanson (2015)'s forward guidance factor and $Z_{2}$ share similar patterns around the dates included in our sample. Results are available upon request.
} 
Fed communication are concentrated on longer-dated yields.

Similarly to the exercise depicted in Figure 3, we use intraday data to estimate the sensitivity of yields to $Z_{2}$ around the time of Fed statement releases to help us assess on whether the yieldbased measure $Z_{2}$ captures Fed communication. Results show that the sensitivity of yields to $Z_{2}$ declines as the estimation moves away from the announcement (see Appendix Figure A2). These results give credence to the view that $Z_{2}$ does indeed capture Fed communication in both the pre- and the ZLB periods.

\subsection{A horse race}

Our results suggest that both $\triangle F S O$ and $Z_{2}$ seem to capture Fed communication in both the pre- and the ZLB periods. Comparing the two measures, however, the correlation between $\triangle F S O$ and $Z_{2}$ in the full sample is only 0.26 . This suggests that, while these measures share some similarities, they may also capture different dimensions of Fed communication. Indeed, when we compare the measures in the pre-ZLB and ZLB samples, we find that their correlation is much stronger in the first part of the sample, at 0.32, versus 0.06 during the ZLB period.

To investigate this issue further, we redo our baseline regressions including the two measures of Fed communication surprises at the same time. Table 7 reports the results. Panel A shows that, in the pre-ZLB period, the yield-based communication measure $Z_{2}$ "crowds out" the semantic communication measure $\triangle F S O$. This does not happen during the ZLB period, when both measures of communication retain their statistical significance (Panel B). ${ }^{27}$

These results suggest that the nature of Fed communication may have changed over time. ${ }^{28}$ In normal times, the two measures of communication that we analyze correlate, and the yieldbased measure seems to suffice. This may not come as a big surprise, precisely because the latter measure is extracted from (short-term) yields. However, despite this fact, the semantic measure retains its statistical significance in the ZLB period, suggesting that it contains relevant information that is not captured by the yield-based measure.

\footnotetext{
27 In unreported results, we find that, for this more limited sample of dates, if we only include $\Delta F S O$ as a measure of communication, its estimated effect is only statistically significant for changes in 10-year yields. In addition, results based on intraday data are not statistically significant. In the later estimation, however, because our sample of intraday dates does not include testimonies, the number of observations is reduced to only 30 . Hence, these results might hinge on the small sample size.

28 Meade and Acosta (2015) highlight the increasing number of words used in FOMC statements since the Great Recession, and Hernández-Murillo and Shell (2014) argue that FOMC statements have become more complex during the ZLB.
} 
Table 7: Effects of the semantic- and the yield-based measures of Fed communication $(\triangle F S O$ and $Z_{2}$ ) on yields: a horse race

\begin{tabular}{|c|c|c|c|c|c|}
\hline \multicolumn{6}{|c|}{ Panel A: Pre-ZLB period } \\
\hline & \multicolumn{5}{|c|}{ Treasury yields: } \\
\hline & 3-month & 6-month & 2-years & 5-years & 10-years \\
\hline \multirow{2}{*}{ Communication $\left(\beta_{\triangle F S O}\right)$} & 0.39 & -0.03 & 0.18 & -0.07 & -0.23 \\
\hline & $(0.5)$ & $(0.29)$ & $(0.23)$ & $(0.32)$ & $(0.32)$ \\
\hline \multirow{2}{*}{ Communication $\left(\beta_{Z_{2}}\right)$} & $0.05^{* *}$ & $0.11^{* * *}$ & $0.24^{* * *}$ & $0.24^{* * *}$ & $0.19^{* * *}$ \\
\hline & $(0.02)$ & $(0.02)$ & $(0.01)$ & $(0.02)$ & $(0.02)$ \\
\hline \multirow[t]{2}{*}{ Mon. Surprise $(\gamma)$} & $0.48^{* * *}$ & $0.45^{* * *}$ & $0.32^{* * *}$ & $0.20^{* *}$ & 0.12 \\
\hline & $(0.13)$ & $(0.1)$ & $(0.06)$ & $(0.08)$ & $(0.07)$ \\
\hline$R^{2}$ & 0.39 & 0.51 & 0.82 & 0.7 & 0.57 \\
\hline \multirow[t]{4}{*}{ Observations } & 151 & 151 & 151 & 151 & 151 \\
\hline & \multicolumn{5}{|c|}{ Panel B: ZLB period } \\
\hline & \multicolumn{5}{|c|}{ Treasury yields: } \\
\hline & 3-month & 6-month & 2-years & 5-years & 10-years \\
\hline \multirow{2}{*}{ Communication $\left(\beta_{\triangle F S O}\right)$} & -0.04 & -0.02 & 0.45 & $0.79^{*}$ & $0.93^{* *}$ \\
\hline & $(0.08)$ & $(0.08)$ & $(0.3)$ & $(0.4)$ & $(0.47)$ \\
\hline \multirow[t]{2}{*}{ Communication $\left(\beta_{Z_{2}}\right)$} & $0.03^{* *}$ & $0.02^{* *}$ & $0.15^{* * *}$ & $0.21^{* *}$ & $0.19^{* *}$ \\
\hline & $(0.01)$ & $(0.01)$ & $(0.05)$ & $(0.08)$ & $(0.08)$ \\
\hline \multirow[t]{2}{*}{ Mon. Surprise $(\gamma)$} & 0.37 & 0.4 & 0.76 & 1.32 & 0.82 \\
\hline & $(0.5)$ & $(0.37)$ & $(1.34)$ & $(2.3)$ & $(2.07)$ \\
\hline$R^{2}$ & 0.13 & 0.15 & 0.33 & 0.25 & 0.21 \\
\hline Observations & 69 & 69 & 69 & 69 & 69 \\
\hline
\end{tabular}

Note: This table provides results for the estimation of $\Delta y_{d}^{m}=\alpha^{m}+\beta_{\Delta F S O}^{m} \Delta F S O_{d}+\beta_{Z_{2}}^{m} Z_{2, d}+\gamma^{m} M S_{d}+\varepsilon_{d}^{m}$, where $\Delta y_{d}^{m}$ is the change in Treasury yields of bonds with maturity $m$ around a "communication date" $d$, and $M S_{d}$ measures interest rate surprises using $Z_{1}$ around a date $d$. Communication dates are those of FOMC statement releases and dates of testimonies by the Chair of the Federal Reserve Board, excluding dates of LSAPs announcements as listed in the Appendix Table A1. The pre-ZLB sample goes from May 18, 1999 to December 15, 2008. The ZLB period goes from December 16, 2008 to December 17, 2014. Details about measures of communication and interest rate surprises are provided in Sections 2 and 5. Heteroskedasticity-consistent standard errors are reported in parentheses. Coefficients followed by ${ }^{* * *},{ }^{* *}$, or ${ }^{*}$ are statistically significant at the $1 \%, 5 \%$, or $10 \%$ levels, respectively.

\section{Conclusion}

With the policy rate at its effective zero lower bound, the Federal Reserve resorted to unconventional monetary policy measures — namely asset purchases and communication — in trying to stimulate the economy and shape expectations. 
In this paper we assess whether the ZLB has indeed posed such a constraint to the monetary authority by focusing on and comparing the effects of Fed communication during the pre-ZLB and the ZLB periods. We do so by relying on a methodology developed by Lucca and Trebbi (2011) and constructing a newspaper-based measure of communication surprises and comparing its effects on yields of different maturities in the two aforementioned periods.

We find that during the pre-ZLB period, communication surprises affected yields of both short- and long-term maturities. Since 2008, however, while the sensitivity of short-term yields diminishes, the estimated effects of communication surprises on longer-dated yields is basically unchanged. We resort to a yield-decomposition based on a no-arbitrage affine term-structure model, and find that, during both the pre-ZLB and the ZLB periods, the effects of communication concentrate on the risk-neutral components of yields. Finally, we also compare our findings to those obtained using a yield-based measure of communication, following Gürkaynak, Sack and Swanson, 2005 and Swanson, 2015. We find that the results of the yield- and the semantic-based measures of communication corroborate and complement each other.

Taken together, our results complement the findings of Swanson and Williams (2014), who show that during the ZLB long-term yields still responded to macroeconomic surprises. Building on their insight, we show that, despite the ZLB, Fed communication surprises still affected long-term yields, providing more direct evidence that monetary policy has not been all that constrained by the ZLB.

\section{References}

Bassetto, Marco. 2015. "Forward Guidance: Communication, Commitment, or Both?" Manuscript. Downloaded on July 15, 2015 from http://users.nber.org/ bassetto/ research/ulysses/ulysses.pdf.

Bauer, Michael D., and Glenn D. Rudebusch. 2014. "The signaling channel for Federal Reserve bond purchases." International Journal of Central Banking, 10(3): pp. 233-289.

Bernanke, Ben S., and Kenneth N. Kuttner. 2005. "What Explains the Stock Market's Reaction to Federal Reserve Policy?" The Journal of Finance, 60(3): 1221-1257.

Campbell, Jeffrey R., Alejandro Justiniano, Charles L. Evans, and Jonas D.M. Fisher. 2012. "Macroeconomic Effects of FOMC Forward Guidance." Brookings Papers on Economic Activity, 44(1): pp. 1-80. 
Carlstrom, Charles, Timothy Fuerst, and Matthias Paustian. 2012. "How Inflationary Is an Extended Period of Low Interest Rates." Federal Reserve Bank of Cleveland Working Paper 12-02.

Chen, Han, Vasco Cúrdia, and Andrea Ferrero. 2012. "The Macroeconomic Effects of Large-scale Asset Purchase Programmes." The Economic Journal, 122(564): F289-F315.

Christensen, Jens H. E., and Glenn D. Rudebusch. 2016. "Modeling Yields at the Zero Lower Bound: Are Shadow Rates the Solution?" Dynamic Factor Models, Chapter 9, 75-125.

Cragg, John G., and Stephen G. Donald. 1997. "Inferring the rank of a matrix." Journal of Econometrics, 76(12): 223 - 250 .

Cúrdia, Vasco, and Michael Woodford. 2011. "The central-bank balance sheet as an instrument of monetarypolicy." Journal of Monetary Economics, 58(1): 54 - 79. Carnegie-Rochester Conference Series on Public Policy: The Future of Central Banking April 16-17, 2010.

Del Negro, Marco, Marc Giannoni, and Christina Patterson. 2015. "The Forward Guidance Puzzle." Federal Reserve Bank of New York Staff Report 574.

Eggertsson, Gauti B., and Michael Woodford. 2003. "The Zero Bound on Interest Rates and Optimal Monetary Policy." Brookings Papers on Economic Activity, 1.

Gürkaynak, Refet S., Brian Sack, and Eric T. Swanson. 2005. "Do Actions Speak Louder Than Words? The Response of Asset Prices to Monetary Policy Actions and Statements." International Journal of Central Banking, 1(1): 55-93.

Hansen, Stephen, and Michael McMahon. 2016. "Shocking language: Understanding the macroeconomic effects of central bank communication." Journal of International Economics, 99, Supplement 1: S114 - S133. 38th Annual NBER International Seminar on Macroeconomics.

Hernández-Murillo, Rubén, and Hannah Shell. 2014. "The Rising Complexity of the FOMC Statement." Federal Reserve Bank of St. Louis Economic Synopses 23.

Krishnamurthy, Arvind, and Annette Vissing-Jorgensen. 2011. "The Effects of Quantitative Easing on Interest Rates: Channels and Implications for Policy." Brookings Papers on Economic Activity, 43(2 (Fall)): 215-287.

Kuttner, Kenneth N. 2001. "Monetary policy surprises and interest rates: Evidence from the Fed funds futures market." Journal of Monetary Economics, 47(3): 523-544. 
Lucca, David O., and Emanuel Moench. 2015. "The Pre-FOMC Announcement Drift." The Journal of Finance, 70(1): 329-371.

Lucca, David O., and Francesco Trebbi. 2011. "Measuring Central Bank Communication: An Automated Approach with Application to FOMC Statements." Working Paper. Available at http://faculty.arts.ubc.ca/ftrebbi/research/lt.pdf.

McKay, Aliasdair, Emi Nakamura, and Jón Steinsson. 2015. "The Power of Forward Guidance Revisited." American Economic Review, forthcoming.

Meade, Ellen E., and Miguel Acosta. 2015. "Hanging on every word: Semantic analysis of the FOMC's postmeeting statement." Board of Governors of the Federal Reserve System FEDS Notes 2015-09-30.

Rudebusch, Glenn D. 1998. "Do Measures of Monetary Policy in a Var Make Sense?" International Economic Review, 39(4): pp. 907-931.

Swanson, Eric T. 2011. "Let's Twist Again: A High-Frequency Event-study Analysis of Operation Twist and Its Implications for QE2." Brookings Papers on Economic Activity, 42(1): 151207.

Swanson, Eric T. 2015. "Measuring the Effects of Unconventional Monetary Policy on Asset Prices." National Bureau of Economic Research Working Paper 21816.

Swanson, Eric T., and John C. Williams. 2014. "Measuring the Effect of the Zero Lower Bound on Medium- and Longer-Term Interest Rates." American Economic Review, 104(10): 3154-85.

Williams, John C. 2011. "Unconventional Monetary Policy: Lessons from the Past Three Years." FRBSF Economic Letter, 2011-31. 


\section{A Appendix}

Table A1: Dates of FOMC statements and testimonies by the Chair of the Federal Reserve

\begin{tabular}{|c|c|}
\hline \multicolumn{2}{|r|}{ Statement release dates } \\
\hline Pre-ZLB & $\begin{array}{l}\text { 1999: May 18, Jun 30, Aug 24, Oct 05, Nov 16, Dec } 21 \\
\text { 2000: Feb 02, Mar 21, May 16, Jun 28, Aug 22, Oct 03, Nov 15, Dec } 19 \\
\text { 2001: Jan 03, Jan 31, Mar 20, Apr 18, May 15, Jun 27, Aug 21, Sep 17, Oct 02, Nov 06, Dec } 11 \\
\text { 2002: Jan 30, Mar 19, May 07, Jun 26, Aug 13, Sep 24, Nov 06, Dec } 10 \\
\text { 2003: Jan 29, Mar 18, May 06, Jun 25, Aug 12, Sep 16, Oct 28, Dec } 09 \\
\text { 2004: Jan 28, Mar 16, May 04, Jun 30, Aug 10, Sep 21, Nov 10, Dec } 14 \\
\text { 2005: Feb 02, Mar 22, May 03, Jun 30, Aug 09, Sep 20, Nov 01, Dec } 13 \\
\text { 2006: Jan 31, Mar 28, May 10, Jun 29, Aug 08, Sep 20, Oct 25, Dec } 12 \\
\text { 2007: Jan 31, Mar 21, May 09, Jun 28, Aug 07, Aug 17, Sep 18, Oct } 31 \text {, Dec } 11 \\
\text { 2008: Jan 22, Jan 30, Mar 11, Mar 18, Apr 30, Jun 25, Aug 05, Sep 16, Oct } 08 \text {, Oct } 29\end{array}$ \\
\hline ZLB & $\begin{array}{l}\text { 2008: Dec 16 } \\
\text { 2009: Jan 28, Mar 18, Apr 29, Jun 24, Aug 12, Sep 23, Nov 04, Dec } 16 \\
\text { 2010: Jan 27, Mar 16, Apr 28, Jun 23, Aug 10, Sep 21, Nov 03, Dec } 14 \\
\text { 2011: Jan 26, Mar 15, Apr 27, Jun 22, Aug 09, Sep 21, Nov 02, Dec } 13 \\
\text { 2012: Jan 25, Mar 13, Apr 25, Jun 20, Aug 01, Sep 13, Oct 24, Dec } 12 \\
\text { 2013: Jan 30, Mar 20, May 01, Jun 19, Jul 31, Sep 18, Oct 30, Dec 18 } \\
\text { 2014: Jan 29, Mar 19, Apr 30, Jun 18, Jul 30, Sep 17, Oct 29, Dec } 17 \\
\text { Testimony dates }\end{array}$ \\
\hline Pre-ZLB & $\begin{array}{l}\text { 1999: May 20, Jun 14, Jun 17, Jul 22 } \\
\text { 2000: Jan 26, Feb 10, Feb 17, Mar 27, Apr 13, Jun 21, Jul 20, Sep } 21 \\
\text { 2001: Jan 25, Feb 13, Feb 28, Mar 02, Apr 04, Jun 20, Jul 18, Sep 20, Oct } 17 \\
\text { 2002: Jan 24, Feb 05, Feb 27, Mar 07, Apr 17, Apr 23, Jul 16, Sep 12, Nov } 13 \\
\text { 2003: Feb 11, Apr 30, May 21, Jun 10, Jul 10, Jul 15 } \\
\text { 2004: Feb 11, Mar 11, Jun 15, Jul 20, Sep 08 } \\
\text { 2005: Feb 16, Mar 15, Apr 06, Apr 21, Jun 09, Jun 23, Jul 20, Nov } 03 \\
\text { 2006: Feb 15, Apr 27, May 23, Jul 19 } \\
\text { 2007: Jan 18, Feb 14, Feb 28, Mar 28, Jul 18, Sep 20, Nov } 08 \\
\text { 2008: Jan 17, Feb 14, Feb 27, Jul 10, Jul 15, Oct 20, Nov } 18\end{array}$ \\
\hline ZLB & $\begin{array}{l}\text { 2009: Feb 10, Feb 24, Mar 03, Mar 24, May 05, Jun 03, Jul 21, Jul 24, Oct 01, Dec } 03 \\
\text { 2010: Feb 10, Feb 24, Mar 17, Mar 25, Apr 14, Apr 20, Jun 09, Jul 21, Sep 02, Sep } 30 \\
\text { 2011: Jan 07, Feb 09, Feb 17, Mar 01, Apr 20, May 12, Jul 13, Jul 21, Oct } 04 \\
\text { 2012: Feb 02, Feb 29, Mar 21, Jun 07, Jul 17 } \\
\text { 2013: Feb 26, May 22, Jul 17 } \\
\text { 2014: Feb 11, May 07, Jul 15 }\end{array}$ \\
\hline
\end{tabular}

Note: Dates in bold correspond to LSAP-related announcements. 
Table A2: Effects of the measure of Fed communication $\triangle F S O$ on yields using dates of FOMC statement release dates only

\begin{tabular}{|c|c|c|c|c|c|}
\hline \multicolumn{6}{|c|}{ Panel A: Pre-ZLB period } \\
\hline & \multicolumn{5}{|c|}{ Treasury yields: } \\
\hline & 3-month & 6-month & 2-years & 5-years & 10-years \\
\hline Communication $(\beta)$ & $\begin{array}{c}1.30^{*} \\
(0.73)\end{array}$ & $\begin{array}{c}1.47^{* * *} \\
(0.48)\end{array}$ & $\begin{array}{c}3.34^{* * *} \\
(0.75)\end{array}$ & $\begin{array}{c}3.17^{* * *} \\
(0.83)\end{array}$ & $\begin{array}{c}2.12^{* * *} \\
(0.76)\end{array}$ \\
\hline Mon. Surprise $(\gamma)$ & $\begin{array}{c}0.61^{* * *} \\
(0.09)\end{array}$ & $\begin{array}{c}0.60^{* * *} \\
(0.05)\end{array}$ & $\begin{array}{c}0.39 * * * \\
(0.09)\end{array}$ & $\begin{array}{l}0.25^{*} \\
(0.13)\end{array}$ & $\begin{array}{c}0.12 \\
(0.12)\end{array}$ \\
\hline$R^{2}$ & 0.63 & 0.64 & 0.4 & 0.25 & 0.14 \\
\hline Observations & 84 & 84 & 84 & 84 & 84 \\
\hline \multicolumn{6}{|c|}{ Panel B: ZLB period } \\
\hline & \multicolumn{5}{|c|}{ Treasury yields: } \\
\hline & 3-month & 6-month & 2 -years & 5 -years & 10-years \\
\hline Communication $(\beta)$ & $\begin{array}{c}0.07 \\
(0.07)\end{array}$ & $\begin{array}{c}0.29 * * * \\
(0.1)\end{array}$ & $\begin{array}{c}1.66^{* * *} \\
(0.5)\end{array}$ & $\begin{array}{c}3.15^{* * *} \\
(1.1)\end{array}$ & $\begin{array}{c}2.48^{* *} \\
(1.05)\end{array}$ \\
\hline Mon. Surprise $(\gamma)$ & $\begin{array}{c}0.16^{* * *} \\
(0.02)\end{array}$ & $\begin{array}{c}-0.13^{* * *} \\
(0.04)\end{array}$ & $\begin{array}{c}0.91^{* * *} \\
(0.15)\end{array}$ & $\begin{array}{c}1.87^{* * *} \\
(0.37)\end{array}$ & $\begin{array}{c}2.28^{* * *} \\
(0.3)\end{array}$ \\
\hline$R^{2}$ & 0.13 & 0.2 & 0.34 & 0.31 & 0.3 \\
\hline Observations & 49 & 49 & 49 & 49 & 49 \\
\hline
\end{tabular}

Note: The table provides results for the estimation of $\Delta y_{d}^{m}=\alpha^{m}+\beta^{m} C S_{d}+\gamma^{m} M S_{d}+\varepsilon_{d}^{m}$, where $\Delta y_{d}^{m}$ is the change in Treasury yields of bonds with maturity $m$ around a "communication date" $d, C S_{d}$ measures communication surprises using $\triangle F S O$, and $M S_{d}$ measures interest rate surprises using Kuttner surprises around a date $d$. Sample only includes FOMC statement release dates. The pre-ZLB sample goes from May 18, 1999 to December 15, 2008. The ZLB period goes from December 16, 2008 to December 17, 2014. Details about measures of communication and interest rate surprises are provided in Section 2. Heteroskedasticity-consistent standard errors are reported in parentheses. Coefficients followed by ${ }^{* * *},{ }^{* *}$, or ${ }^{*}$ are statistically significant at the $1 \%, 5 \%$, or $10 \%$ levels, respectively. 
Figure A1: Monetary policy and communication surprises: Kuttner surprises and the yieldbased measures $Z_{1}$ and $Z_{2}$
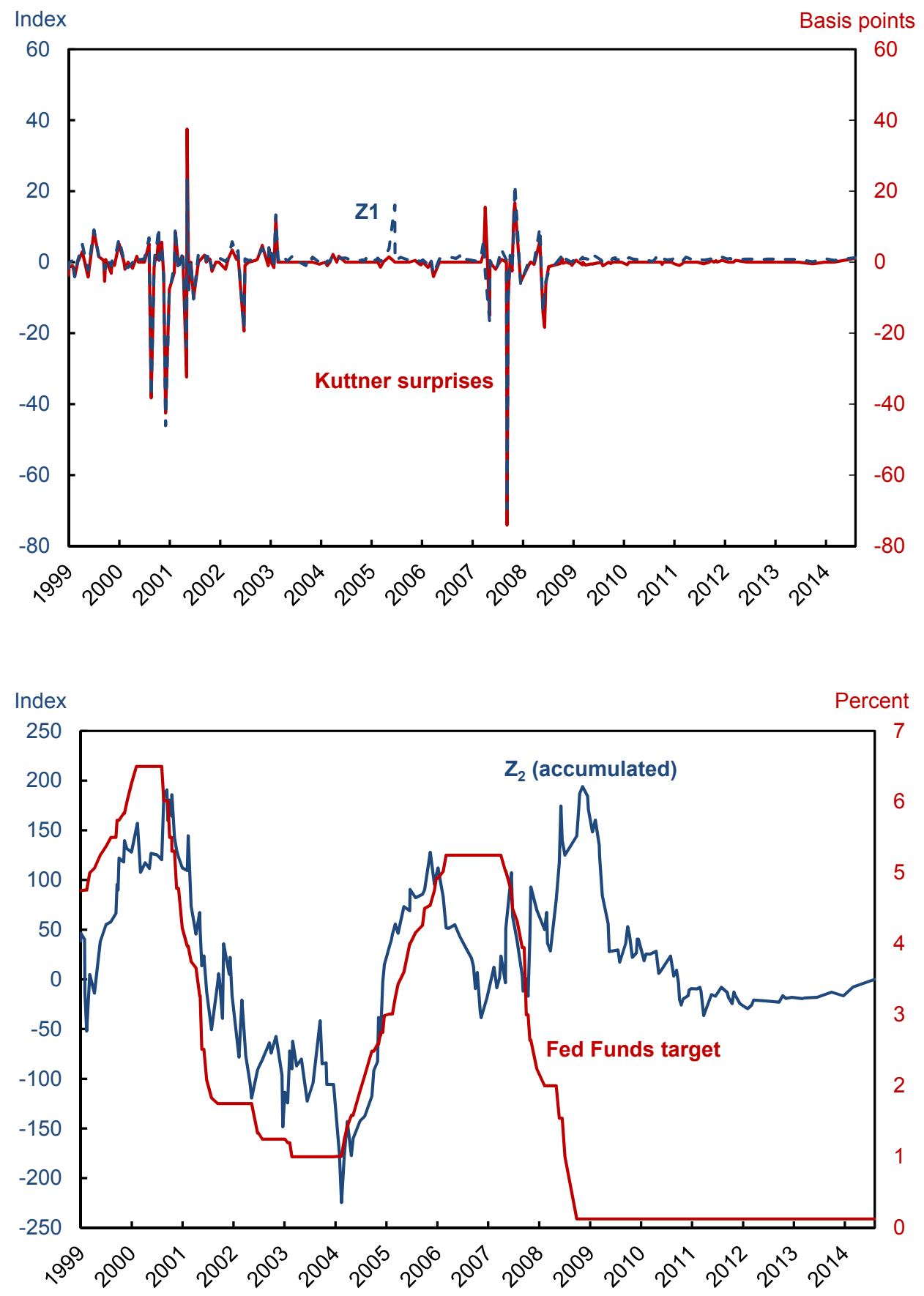

Note: Top panel: "Kuttner surprises" are measured as the (scaled) yield changes of federal funds futures contracts for the current-month. The target factor $Z_{1}$ is the (normalized) rotated and orthogonalized first principal component extracted from a panel of short-term yields. See Sections 2 and 5 for detailed descriptions. Bottom panel: The path factor $Z_{2}$ is the normalized rotated second principal component extracted from a panel of short-term yields. See Section 5 for a detailed description. 
Figure A2: Effect of the yield-based measure of Fed communication $\left(Z_{2}\right)$ on yields outside announcement times
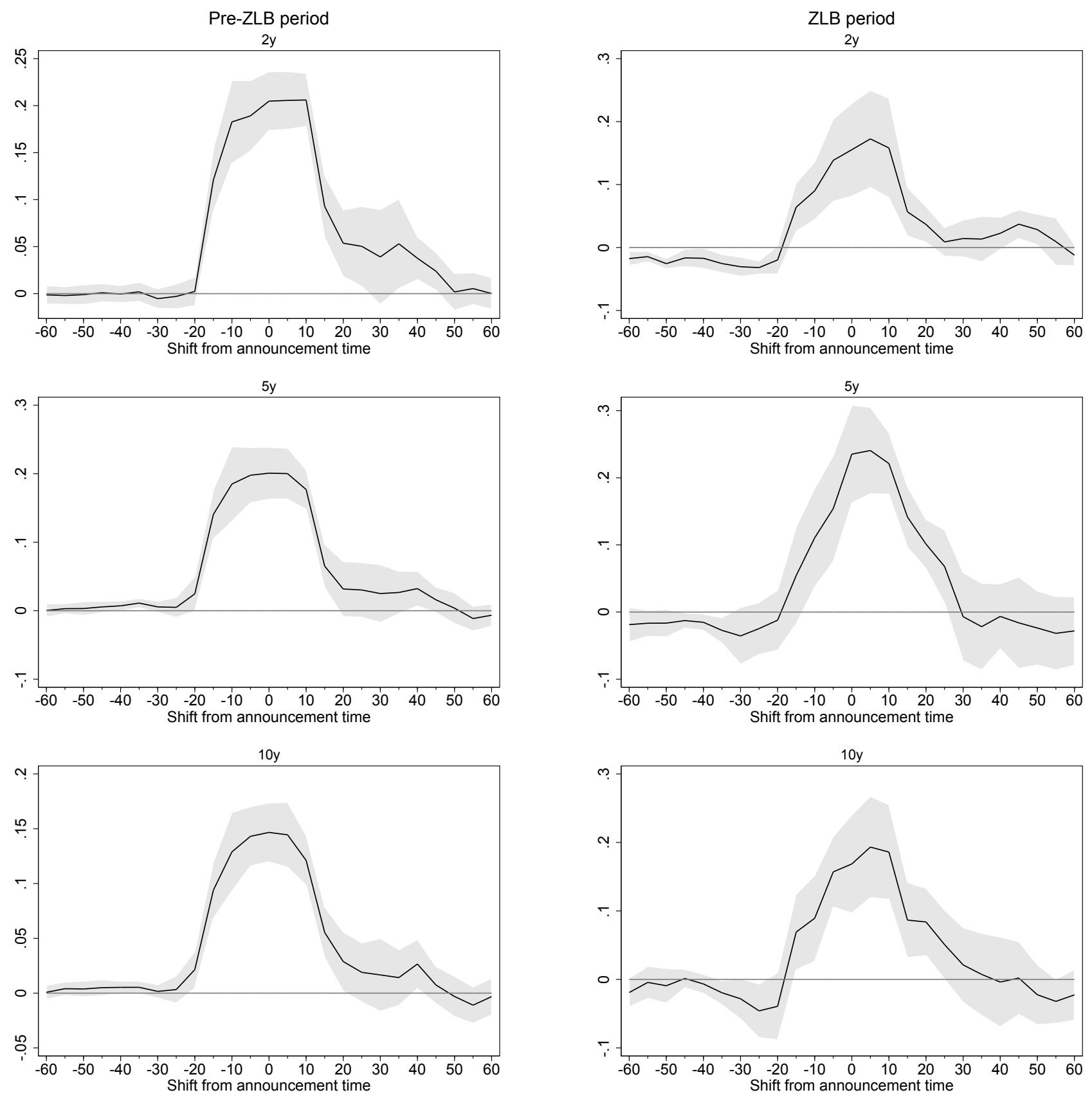

Note: This figure the effects of the yield-based measure of communication $\left(Z_{2}\right)$ resulting from the estimation of the regression $\Delta y_{d}^{m}=\alpha^{m}+\beta^{m} C S_{d}+\gamma^{m} M S_{d}+\varepsilon_{d}^{m}$, where $\Delta y_{d}^{m}$ is the change in Treasury yields of bonds with maturity $m$ around a "communication date" $d, C S_{d}$ measures communication surprises using $Z_{2}$, and $M S_{d}$ measures interest rate surprises using $Z_{1}$ around a date $d$. Communication dates are those of FOMC statement releases. $\Delta y_{d}^{m}$ are calculated within a 30-minute window centered at 1 hour before to one hour after FOMC statement releases. Time 0 in each panel marks the announcement time. Details about measures of communication and interest rate surprises are provided in Section 5. Details about this exercise are provided in Section 4 . The shaded regions represent $90 \%$ confidence intervals based on heteroskedastic-consistent standard errors. 
Figure A3: Effects of the measure of Fed communication $\triangle F S O$ on yields' risk-neutral and term-premium components over time: rolling regressions
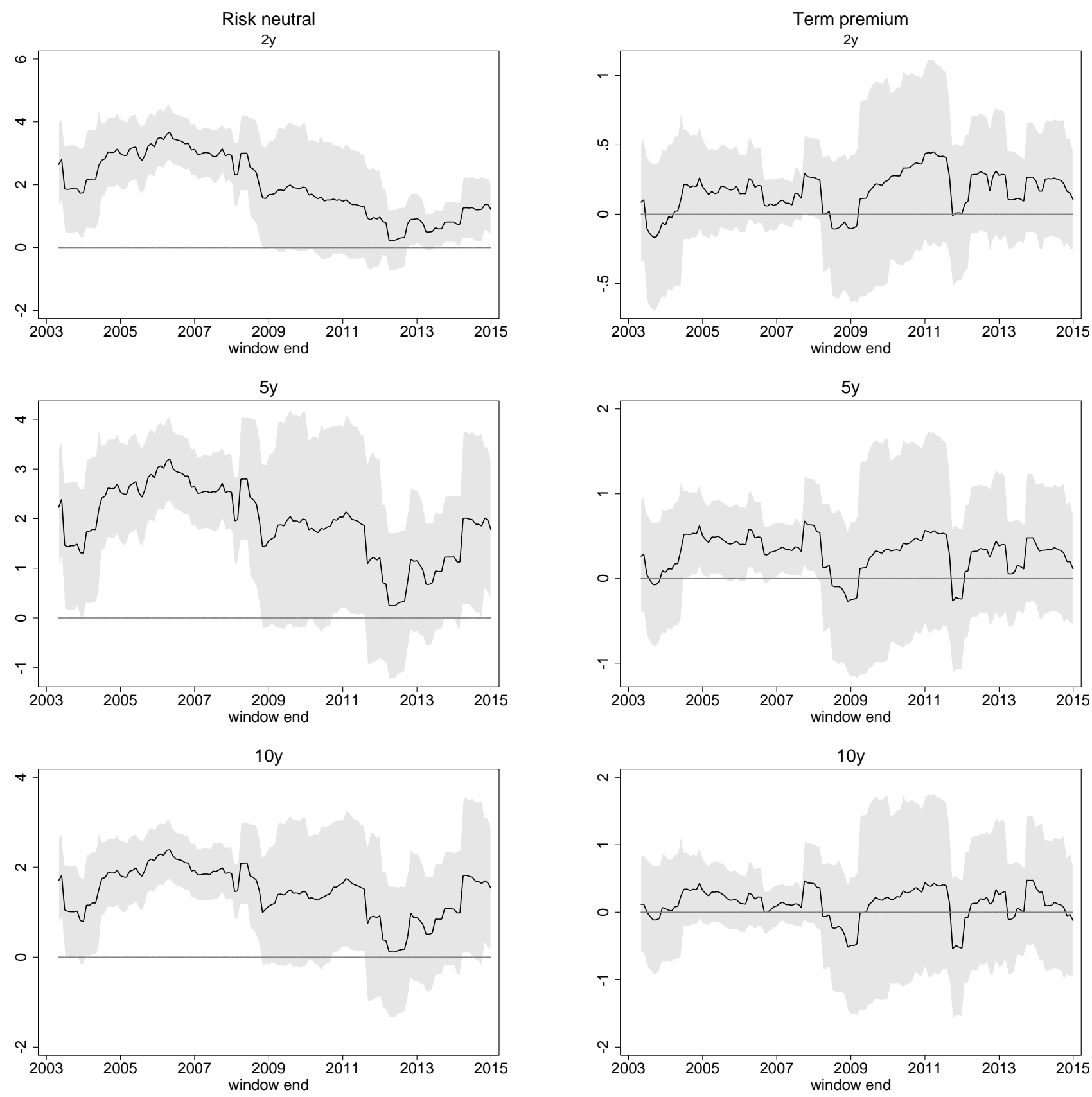

Note: The figure shows the effects of the semantic-based measure of communication $(\triangle F S O)$ resulting from the estimation of the regression $\Delta y_{d}^{m}=\alpha^{m}+\beta^{m} C S_{d}+\gamma^{m} M S_{d}+\varepsilon_{d}^{m}$, where $\Delta y_{d}^{m}$ is the change in the risk neutral and the term premium components of Treasury yields of bonds with maturity $m$ around a "communication date" $d, C S_{d}$ measures communication surprises using $\triangle F S O$, and $M S_{d}$ measures interest rate surprises using Kuttner surprises around a date $d$. Communication dates are those of FOMC statement releases and dates of testimonies by the Chair of the Federal Reserve Board. Treasury yield components are obtained from the estimation of a shadow-rate dynamic term structure model from Christensen and Rudebusch (2016). Details about measures of communication and interest rate surprises, and the yield decomposition are provided in Sections 2 and 4.3. The shaded regions represent $90 \%$ confidence intervals based on heteroskedastic-consistent standard errors. 